University of Nebraska - Lincoln

DigitalCommons@University of Nebraska - Lincoln

Ostertagia ostertagi macrophage migration inhibitory factor is present in all developmental stages and may cross-regulate host functions through interaction with the host receptor

Guanggang Qu

Raymond Fetterer

Lin Leng

Xin Du

Dante Zarlenga

See next page for additional authors

Follow this and additional works at: https://digitalcommons.unl.edu/usdaarsfacpub

This Article is brought to you for free and open access by the U.S. Department of Agriculture: Agricultural Research Service, Lincoln, Nebraska at DigitalCommons@University of Nebraska - Lincoln. It has been accepted for inclusion in Publications from USDA-ARS / UNL Faculty by an authorized administrator of DigitalCommons@University of Nebraska - Lincoln. 


\section{Authors}

Guanggang Qu, Raymond Fetterer, Lin Leng, Xin Du, Dante Zarlenga, Zhiqiang Shen, Wenyu Han, Richard Bucala, and Wenbin Tuo 


\title{
Ostertagia ostertagi macrophage migration inhibitory factor is present in all developmental stages and may cross-regulate host functions through interaction with the host receptor
}

\author{
Guanggang Qu ${ }^{\mathrm{a}, \mathrm{b}}$, Raymond Fetterer ${ }^{\mathrm{a}}$, Lin Leng ${ }^{\mathrm{c}}$, Xin Du ${ }^{\mathrm{c}}$, Dante Zarlenga ${ }^{\mathrm{a}}$, Zhiqiang Shen ${ }^{\mathrm{b}}$, \\ Wenyu Han ${ }^{\mathrm{d}}$, Richard Bucala ${ }^{\mathrm{c}}$, Wenbin Tuo ${ }^{\mathrm{a}, *}$ \\ a Animal Parasitic Diseases Laboratory, Agricultural Research Service, USDA, Beltsville, MD 20705, USA \\ b Shangdong Binzhou Academy of Animal Science and Veterinary Medicine, Binzhou City, Shandong 256600, China \\ ${ }^{\mathrm{c}}$ Department of Medicine, Yale University School of Medicine, New Haven, CT 06520, USA \\ ${ }^{\mathrm{d}}$ College of Veterinary Medicine and Animal Science, Jilin University, Changchun, China
}

\section{A R T I C L E I N F O}

\section{Article history:}

Received 30 September 2013

Received in revised form 31 December 2013

Accepted 6 January 2014

Available online 28 February 2014

\section{Keywords:}

Ostertagia ostertagi

Macrophage migration inhibitory factor

Oos-MIF

Cattle

Nematode

\begin{abstract}
A B S T R A C T
Macrophage migration inhibitory factor (MIF) of Ostertagia ostertagi, an abomasal parasite of cattle, was characterised in the present study. Phylogenetic analysis identified at least three 0 . ostertagi MIFs (OosMIFs), each encoded by a distinct transcript: Oos-MIF-1.1, Oos-MIF-1.2 and Oos-MIF-2. Oos-MIF-2 is only distantly related to Oos-MIF-1s, but has higher sequence similarity with the Caenorhabditis elegans MIF2. Oos-MIF-1.1 and Oos-MIF-1.2 are similar (93\%) and thus collectively referred to as Oos-MIF-1 when characterised with immunoassays. Recombinant Oos-MIF-1.1 (rOos-MIF-1.1) is catalytically active as a tautomerase. A mutation (rOos-MIF-1.1P1G) or duplication of Pro1 residue (rOos-MIF-1.1P1+P) resulted in reduced oligomerisation and loss of tautomerase activity. The tautomerase activity of rOos-MIF-1.1 was only partially inhibited by ISO-1 but was abrogated by a rOos-MIF-1.1-specific antibody. Oos-MIF1 was detected in all developmental stages of $O$. ostertagi, with higher levels in the adult stage; it was also detected in adult worm excretory/secretory product. Oos-MIF-1 was localised to the hypodermis/muscle, reproductive tract and intestine, but not to the cuticle. rOos-MIF-1.1, but not rOos-MIF-1.1P1G, was able to specifically bind to human CD74, a MIF cell surface receptor, with an affinity comparable with human MIF. Immunostaining indicated that macrophages were able to internalise rOos-MIF-1.1, further supporting receptor-mediated transportation. Herein we also show that rOos-MIF-1.1 inhibited migration of bovine macrophages and restored glucocorticoid-suppressed, lipopolysaccharide-induced TNF- $\alpha$ and IL-8 in human and/or bovine macrophages. Given its dual role in self-regulation and molecular mimicry, this secreted parasite protein warrants investigation as a vaccine candidate against 0 . ostertagi infections in cattle.
\end{abstract}

Published by Elsevier Ltd. on behalf of Australian Society for Parasitology Inc.

\section{Introduction}

Parasitic nematodes are notorious in their ability to regulate host immunity and evade immune surveillance. In part, this effect is accomplished by producing bioactive molecules which possess potent immunoregulatory functions. To date, macrophage migration inhibitory factor (MIF), a cytokine activity first described decades ago, has been characterised in Caenorhabditis elegans and a number of parasitic nematodes (Vermeire et al., 2008). Mammalian MIF is involved in septic shock (Bernhagen et al., 1993), regulates macrophage (Calandra et al., 1994; Onodera et al., 1997) and

\footnotetext{
* Corresponding author.

E-mail address: wenbin.tuo@ars.usda.gov (W. Tuo).
}

lymphocyte responses, and affects endocrine function (Bacher et al., 1996; Abe et al., 2001; Fingerle-Rowson and Bucala, 2001). MIF also inhibits the random migration of monocytes/ macrophages, the anti-inflammatory effects of glucocorticoids (Calandra et al., 1994), and it upregulates Toll-like receptor 4 (TLR4) expression by immune cells (Roger et al., 2003) and proinflammatory cytokines (TNF $\alpha$, IL-1 $\beta$, IL-6, IL-8 and IL-12) (Calandra et al., 1994; Bacher et al., 1996; Donnelly et al., 1999). MIF is produced by a wide variety of cell types, including lymphocytes, monocytes/macrophages, endothelial cells and fibroblasts (Calandra and Roger, 2003). Its biological effects are mediated by a receptor complex involving CD74 (Leng et al., 2003), CD44 (Shi et al., 2006) and CXC chemokine receptors (Bernhagen et al., 2007). 
MIF possesses oxidoreductase and tautomerase activities which may be associated with its immunological function (Sun et al., 1996a,b; Suzuki et al., 1996). The protein's conserved C-XX-C motif is associated with the oxidoreductase activity, and the $\mathrm{N}$-terminal proline (Pro1) acts as a catalytic base for tautomerase activity (Bendrat et al., 1997; Stamps et al., 1998). MIF tautomerase activity can be inhibited by ISO-1 and other small-molecule inhibitors (Lubetsky et al., 2002; Cournia et al., 2009). The crystal structures and sedimentation velocities of bioactive human and mouse MIFs indicate they exist as homotrimers (Philo et al., 2004), although a mixture of monomers, dimers and trimers have been detected (El-Turk et al., 2008). This is similar to a recent report for Neospora caninum MIF (Qu et al., 2013).

Ostertagia ostertagi is a nematode parasite infecting the abomasum of cattle. It is highly prevalent in temperate regions of the world and causes sustained production losses (Williams et al., 1993). Gastrointestinal parasite control is heavily dependent on the use of anthelmintics; however drug resistance is rapidly emerging and requires development of alternatives to drug control. Investigation of the host-parasite interaction, particularly immunomodulation mediated by parasitic cytokines, will aid in further understanding the host response to infection and parasite evasion, and facilitate the development of immunological control measures. MIF homologues have been characterised in a number of parasitic nematodes including Brugia malayi, Trichinella spiralis, Strongyloides ratti, Wuchereria bancrofti, Teladorsagia circumcincta, and Ancylostoma ceylanicum. In each case, they appear to exhibit similar bioactivities to the MIFs of their mammalian hosts (Falcone et al., 2001; Tan et al., 2001; Zang et al., 2002; Cho et al., 2007; Vermeire et al., 2008; Nisbet et al., 2010; Sharma et al., 2012; Younis et al., 2012). In the present study, a secretory 0 . ostertagi MIF (Oos-MIF) was cloned and expressed in Escherichia coli and its production, structural and enzymatic properties, cellular localisation and biological functions were characterised. OosMIF-1 isoforms (1.1 and 1.2) are highly conserved (93\%), and thus are collectively described as Oos-MIF-1 in immunoassays because they may not be distinguishable by polyclonal antibodies. The results of the present study indicate that Oos-MIF-1 is present at various stages of development, suggesting that this cytokine may be involved in regulating host protection and therefore represents a vaccine candidate against seasonal re-infection.

\section{Materials and methods}

\subsection{Oos-MIF gene cloning and sequencing}

A complete open reading frame (ORF) for Oos-MIF was obtained from Oos-MIF cDNA sequences (GenBank accession numbers, BQ457770, BQ457911), an expressed sequence tag (EST) sequence (OS00782) and mRNA transcripts (Oost_isotig14764, Oost_isotig14765, http://www.nematode.net). This Oos-MIF was named Oos-MIF-1.1 (see Section 3.1). Primers were designed to amplify the Oos-MIF gene from adult worm cDNA using a forward primer (5'-GGAATTCCATATGCCGGTTTTCTC-3'; Ndel site underlined) and a reverse primer (5'-ATAAAGCTTTCAAGCAAAAGTTCTGC-3'; HindIII site underlined). A forward primer, 5'-GGAATTCCATATGGGCG TTTTCTCATTCCACAC was used to produce the mutant, rOos-MIF1.1P1G, wherein the proline (Pro) at position 1 was replaced with glycine (Gly). A forward primer, 5'-GGAATTCCATATGCCGCCG GTTTTCTCATTC was used to produce a second Oos-MIF-1.1 mutant, rOos-MIF-1.1P1+P, in which an additional Pro was inserted between Pro1 and Val2. Total RNA was isolated from adult 0 . ostertagi using the RNeasy Mini Kit (Qiagen, Maryland, USA). Two micrograms of total RNA were used to synthesise cDNA using the M-MuLV Reverse Transcriptase Kit (New England Biolabs, Inc, Ipswich, MA, USA). The polymerase chain reaction (PCR) was performed as follows: $95^{\circ} \mathrm{C}$ for 1 min followed by 35 cycles at $95^{\circ} \mathrm{C}$ for $40 \mathrm{~s}, 55^{\circ} \mathrm{C}$ for $30 \mathrm{~s}, 72^{\circ} \mathrm{C}$ for $40 \mathrm{~s}$ with a final extension of $72^{\circ} \mathrm{C}$ for $10 \mathrm{~min}$. The product was purified using a PCR purification kit (Promega, Madison, WI, USA) and ligated into the pGEM-T vector (Promega). The recombinant plasmid was extracted from the E. coli by the Wizard ${ }^{\circledR}$ Plus SV Minipreps (Promega) and sequenced by Functional Biosciences Inc., Madison, WI, USA.

\subsection{Expression, endotoxin removal and purification of rOos-MIF-1.1 and its mutants, and anti-rOos-MIF-1.1 antibody production}

To express the recombinant proteins, the rOos-MIF-1.1, rOosMIF-1.1P1G and rOos-MIF-1.1P1+P genes were subcloned into the pET26b $(+)$ vector (EMD Millipore, San Diego, CA, USA), transformed into E. coli BL21 (DE3) (Novagen, Madison, WI, USA) under kanamycin $(50 \mu \mathrm{g} / \mathrm{ml})$ selection and induced at $30^{\circ} \mathrm{C}$ for $10 \mathrm{~h}$ in the presence of $1 \mathrm{mM}$ isopropyl thiogalactopyranoside (IPTG). After centrifugation at $4,000 \mathrm{~g}$ for $20 \mathrm{~min}$ at $4{ }^{\circ} \mathrm{C}$, the bacteria were lysed by five freeze-thaw cycles in lysis buffer $\left(50 \mathrm{mM} \mathrm{NaH} \mathrm{PO}_{4}\right.$, $300 \mathrm{mM} \mathrm{NaCl}, \mathrm{pH} 8.0$ ) followed by digestion with $10 \mu \mathrm{g} / \mathrm{ml}$ of DNase/RNase for $30 \mathrm{~min}$ at $37^{\circ} \mathrm{C}$. The recombinant protein was found in the soluble fraction following centrifugation at $20,000 \mathrm{~g}$ for $20 \mathrm{~min}$ at $4{ }^{\circ} \mathrm{C}$.

Endotoxin was removed using Triton X-114 (Sigma, St. Louis, MO, USA) prior to HPLC purification (Aida and Pabst, 1990; Qu et al., 2013). In brief, Triton X-114 was added to the soluble lysate to a final concentration of $1 \%$, vortexed for $10 \mathrm{~s}$, incubated on ice for $5 \mathrm{~min}$ then vortexed again. Phase separation occurred when the mix was incubated at $37^{\circ} \mathrm{C}$ for $10 \mathrm{~min}$ and centrifuged at $20,000 \mathrm{~g}$ for $2 \mathrm{~min}$ at $38^{\circ} \mathrm{C}$. The upper aqueous phase containing recombinant protein was retreated seven additional times until endotoxin removal was complete. All recombinant proteins were purified by HPLC using a size exclusion column $(7.7 \times 300 \mathrm{~mm}$, Biosuite $5 \mu \mathrm{m}$ HR; Waters, MA, USA) and eluted with a mobile phase of PBS ( $50 \mathrm{mM} \mathrm{K}_{2} \mathrm{HPO}_{4}, 200 \mathrm{mM} \mathrm{NaCl}, \mathrm{pH} 7.2$ ). The fractions were collected and analysed by SDS-PAGE; a Bicinchoninic Acid (BCA) assay (Thermo Scientific, Rockford, Illinois, USA) was used to determine protein concentrations. The endotoxin levels in Triton X-114 extracted rOos-MIF preparations were undetectable using the endotoxin detection kit (Limulus Amebocyte Lysate QLC-1000, Lonza, Walkersville, MD, USA).

Sheep antisera raised against rOos-MIF-1.1 were produced by immunising a sheep with purified rOos-MIF-1.1 (200 $\mu \mathrm{g} /$ injection). Yearling sheep were pre-screened for cross-reactivity to crude $O$. ostertagi antigen using Western blotting and the sheep that had undetectable cross-reactivity to 0 . ostertagi antigen was used to produce antiserum. Sera were collected following four immunisations at 3-week intervals and stored at $-20^{\circ} \mathrm{C}$ until used. Animal care and use was approved by Beltsville Agricultural Research Center Animal Care and Use Committee, MD, USA.

\subsection{Preparation of crude parasite proteins}

Embryonated eggs were collected from feces by the flotation method using saturated sucrose followed by washes in tap water. Eggs were further purified by Lymphocyte Separation Medium (specific gravity, 1.077; Mediatech Inc., Manasses, VA, USA) followed by two washes in PBS. L3 and adult O. ostertagi were collected and produced using the Baerman technique (for L3s) and/or gel migration method (for adult worms) as described previously (Williams et al., 1987). Crude parasite protein was generated from embryonated eggs, L3s and adult worms by homogenisation in liquid nitrogen in the presence of $1 \mathrm{mM}$ phenylmethylsulfonyl fluoride (PMSF) and $10 \mathrm{mM}$ EDTA. To prepare excretory/secretory (ES) products, adult parasites were washed three times with PBS 
then cultured in serum-free DMEM supplemented with $100 \times$ penicillin/streptomycin, gentamicin (Mediatech, Inc.), Fungizone, and glutamine (Hyclone, Logan, UT, USA) at $37^{\circ} \mathrm{C}$ or $4{ }^{\circ} \mathrm{C}$ for $24 \mathrm{~h}$ (de Graaf et al., 1995). Culture medium was collected by removing the worms using sedimentation followed by centrifugation at $200,000 \mathrm{~g}$ at $4{ }^{\circ} \mathrm{C}$ for $30 \mathrm{~min}$. A protease inhibitor cocktail (Roche, Mannheim, Germany) was added immediately after the parasites were removed from the culture medium. The resultant supernatant was concentrated by ultrafiltration (Millipore, Billerica, MA, USA) with a molecular mass cutoff of 3,000 Da. The protein concentration of all protein samples was determined by a BCA assay (Thermo Scientific). Equal quantities of the total proteins derived from embryonated eggs, L3s and adult worms were analysed by SDS-PAGE and the relative amount of Oos-MIF-1 was determined by Western blotting followed by densitometry.

\subsection{Western blotting}

Western blotting was performed as described previously (Qu et al., 2013). Briefly, samples were separated on a 15\% SDS-PAGE gel under reducing conditions. After protein transfer, the blot was incubated in blocking solution (3\% skim milk in PBS) for $1 \mathrm{~h}$ followed by incubation in sheep anti-Oos-MIF-1.1 serum $(1: 2,000)$ in blocking solution for $1 \mathrm{~h}$ at room temperature. After five washes with wash buffer (0.05\% Tween 20 in PBS), the blot was incubated at room temperature for $1 \mathrm{~h}$ in rabbit antisheep IgG-HRP $(1: 5,000)$ followed by five washes with wash buffer. The blot was developed with a chemiluminescent substrate (SuperSignal ${ }^{\circledR}$ West Dura Exrended Duration Substrate, ThermoFisher, Rockford, IL, USA) according to the manufacturer's instructions. The image was captured and analysed using a Chemilmager ${ }^{\mathrm{TM}}$ 4,400 Low Light Imaging system (Alpha Innotech Corporation, San Leandro, CA, USA). Integrated O.D. of OosMIF-1-specific bands was determined by the above imaging system.

\subsection{Cross-link assay of rOos-MIF-1.1 and its mutant}

An Oos-MIF-1.1 and mutant cross-linking experiment was performed as described previously (Mischke et al., 1998; Qu et al., 2013). In brief, rOos-MIF-1.1 and its mutants at a concentration of $2 \mu \mathrm{g} / \mathrm{ml}$ in $50 \mathrm{mM}$ potassium phosphate buffer at $\mathrm{pH} 6.5$ were incubated in the presence of $1 \%$ glutaraldehyde (Sigma) for $3 \mathrm{~h}$ at RT. The reaction was stopped and the cross-linked products were stabilised in $50 \mathrm{mM} \mathrm{NaBH}_{4}$ for $20 \mathrm{~min}$, followed by washing with $0.01 \%$ sodium deoxycholate (Sigma). The protein then was precipitated by lowering the $\mathrm{pH}$ to 2.0 with trichloroacetic acid (Sigma). After centrifugation (10 $\mathrm{min}, 14,000 \mathrm{~g}$ ), the pellet was washed twice with $100 \mu \mathrm{l}$ of aectone and heated to $75^{\circ} \mathrm{C}$ for $10 \mathrm{~min}$ in $2 \times$ LDS Sample Buffer (NuPAGE, Invitrogen, Carlsbad, CA, USA). Samples were analysed by SDS-PAGE under reducing conditions and silver staining (Sigma).

\subsection{Tautomerase assays}

The tautomerase activity of rOos-MIF-1.1 and its mutants were determined using L-dopachrome methyl ester as reported previously (Pennock et al., 1998; Qu et al., 2013). In brief, $48 \mu \mathrm{l}$ of $10 \mathrm{mM}$ L-3,4-dihydroxyphenylalanine methyl ester (Sigma) and $32 \mu \mathrm{l}$ of $20 \mathrm{mM}$ sodium periodate (Sigma) were mixed with $720 \mu \mathrm{l}$ of buffer $(50 \mathrm{mM}$ potassium phosphate, $1 \mathrm{mM}$ EDTA, $\mathrm{pH}$ 6.2 ) in a $1 \mathrm{ml}$ polystyrene disposable cuvette to generate L-dopachrome methyl ester. The proteins were added to the cuvette and read at $A_{475}$ for 20 min at $10 \mathrm{~s}$ intervals using a spectrophotometer (Beckman, Atlanta, GA, USA). Mouse MIF (Research \& Diagnostics Systems, Inc., Minneapolis, MN, USA)) was used as a positive control. To determine the effect of sheep-anti-rOosMIF-1.1 antibody on tautomerase activity, rOos-MIF-1.1 was incubated with different concentrations of sheep-anti-rOos-MIF-1.1 antibody for $1 \mathrm{~h}$ at room temperature prior to tautomerase assay.

\subsection{Immunolocalisation of Oos-MIF-1}

Adult 0 . ostertagi parasites were harvested, washed briefly in PBS, fixed in $10 \%$ neutral formalin for $12 \mathrm{~h}$, embedded in paraffin and sectioned at $5 \mu \mathrm{m}$ thickness for staining (HistoServe Inc., Germantown, MD, USA). The sections were deparaffinised, quenched with $3 \% \mathrm{H}_{2} \mathrm{O}_{2}$ and rehydrated prior to pepsin digestion $(0.4 \%$ pepsin in $0.01 \mathrm{~N} \mathrm{HCl}$ ) at $37^{\circ} \mathrm{C}$ for $15 \mathrm{~min}$. The slides were washed twice with $0.75 \%$ Brij 35 (Sigma) in PBS (BRIJ-PBS) and blocked with $0.5 \%$ sodium caseinate in BRIJ-PBS for 10 min before incubation for $30 \mathrm{~min}$ at room temperature with the sheep anti-Oos-MIF-1.1 antibody $(1: 1,000)$. After washing, rabbit anti-sheep IgG-horseradish peroxidase (HRP) (1:500) and Dako AEC substrate chromogen (Dako, Carpinteria, CA, USA) were used to visualise antibody binding. Hematoxylin was used as counter-stain prior to applying a coverslip. Pre-bleed sheep serum of similar dilution was used as a negative control. Micrographs were taken using the Zeiss Axioskiope 2 Plus microscope (Zeiss, Thornwood, NY, USA).

\section{8. rOos-MIF-1.1 internalisation by immune cells and competitive binding to the $C D 74$}

rOos-MIF-1.1 internalisation by immune cells was determined using the murine macrophage cell line RAW264.7 and bovine cell line BoMac. Cells cultured in RPMI 1,640 supplemented with $10 \%$ FBS, $25 \mathrm{mM}$ glutamine and $50 \mu \mathrm{g} / \mathrm{ml}$ of gentamicin (complete medium) were seeded in 24-well plates and incubated overnight at $37{ }^{\circ} \mathrm{C}$ in the presence of $5 \% \mathrm{CO}_{2}$. At $60-80 \%$ confluency, cells were rinsed twice with complete medium and co-cultured with or without $10 \mu \mathrm{g} / \mathrm{ml}$ of rOoMIF-1.1 overnight. Cells then were washed twice with PBS and fixed with cold methanol/acetone (1:1) for $20 \mathrm{~min}$ at $-20^{\circ} \mathrm{C}$. The fixative was removed and the cells were air-dried and stored at $4{ }^{\circ} \mathrm{C}$ until stained. Prior to staining, cells were rehydrated with PBS for 5 min, washed three times with PBS then blocked at room temperature for $1 \mathrm{~h}$ in $0.3 \%$ Triton X-100, 1\% BSA, 3\% non-fat skim milk, 5\% FBS in PBS, pH 7.2. Sheep antirOos-MIF-1.1 antibody was diluted $1: 500$ in antibody dilution buffer (1\% BSA, $0.3 \%$ Triton X-100 in PBS, pH 7.2), added to wells and incubated overnight at $4{ }^{\circ} \mathrm{C}$. Controls included secondary antibody alone and medium alone. Following five washes with wash buffer, rabbit anti-sheep IgG labeled with Alexa 488 (KPL, Gaithersburg, MD, USA) diluted 1:1,000 in antibody dilution buffer was added and incubated for $2 \mathrm{~h}$ at room temperature in the dark. Plates were washed four times then incubated with DAPI $(1 \mu \mathrm{g} / \mathrm{ml})$ (Invitrogen) for $5 \mathrm{~min}$ at RT. Plates were washed three times prior to the addition of the mounting medium (glycerol and 10x PBS mixture at 1:9). Images were captured using an inverted, phase-contrast, fluorescence microscope (Olympus, Center Valley PA, USA).

rOos-MIF-1.1 and rOos-MIF-1.1P1G were tested for binding to the human MIF receptor, CD74, as described previously (Leng et al., 2003; Qu et al., 2013). In brief, 96-well plates were coated with recombinant, soluble $\mathrm{CD} 74$ ectodomain $\left(\mathrm{sCD}^{7} 4^{73-232}\right)$. Biotinylated recombinant human MIF (rhMIF; $2.3 \mu \mathrm{g} / \mathrm{ml}$ ) (Roche Applied Sciences, Indianapolis, Indiana, USA) was added in triplicate wells, together with increasing concentrations of purified (non-biotinylated) rhMIF, rOos-MIF-1.1 or rOos-MIF-1.1P1G. The bound biotinylated rhMIF was detected by streptavidin-conjugated alkaline phosphatase (R\&D) using the p-nitrophenyl phosphate substrate (Sigma). Plates were read at $405 \mathrm{~nm}$ and data were plotted as the percentage of $\mathrm{A}_{405}$ relative to wells containing biotinylated rhMIF alone. 


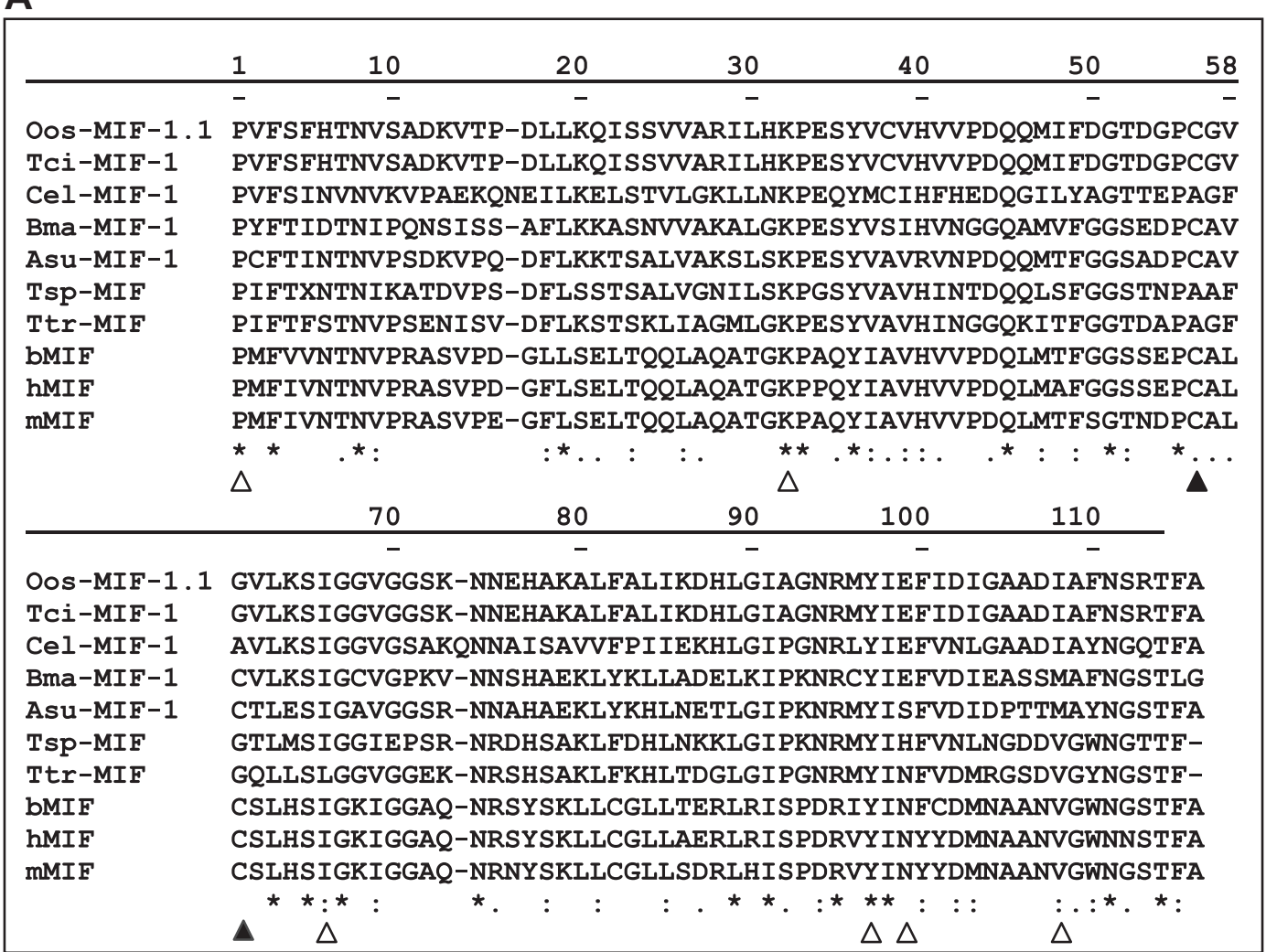

B

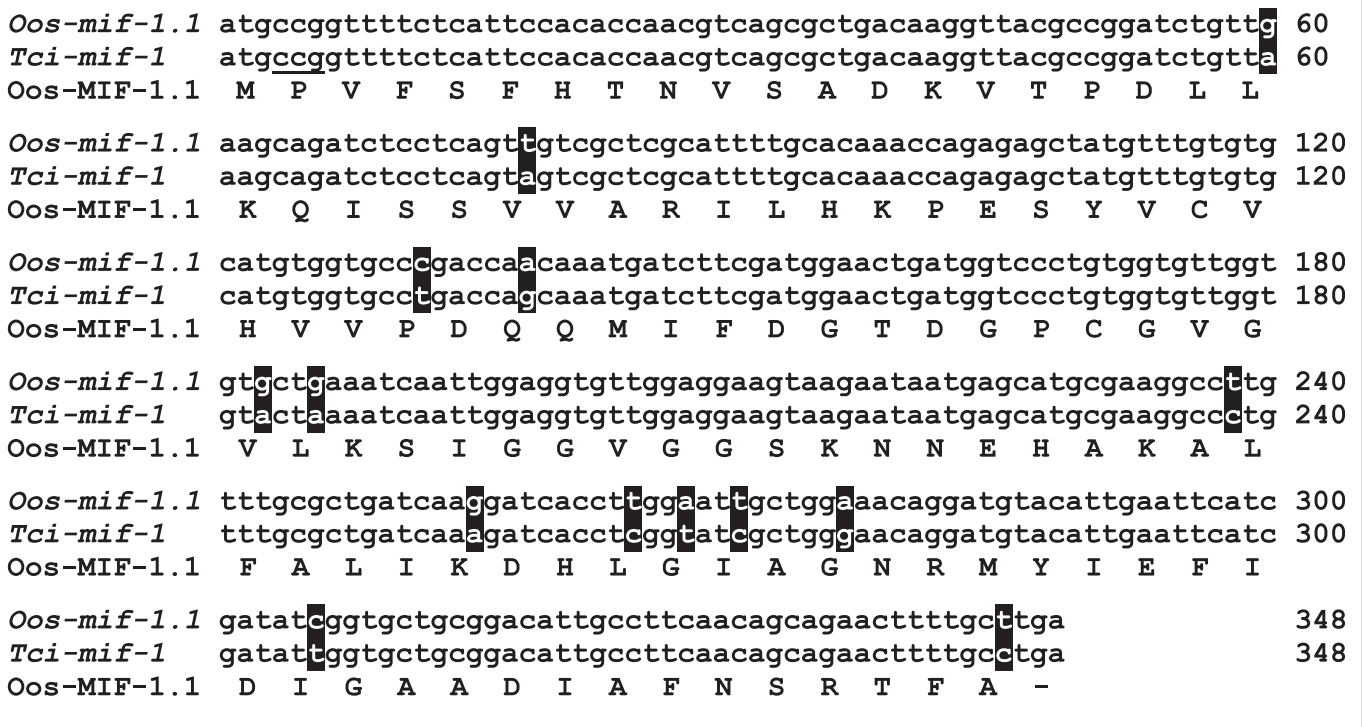

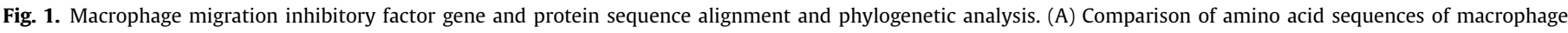

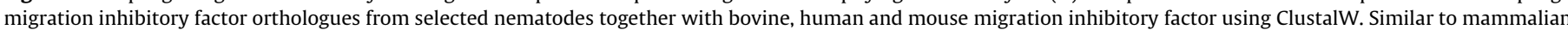

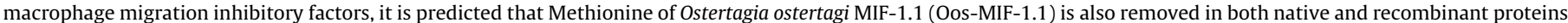

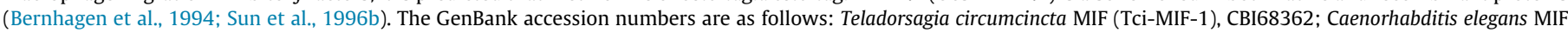

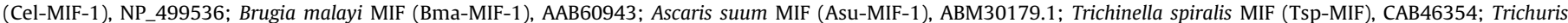

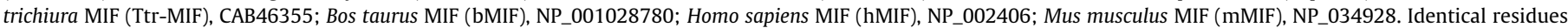

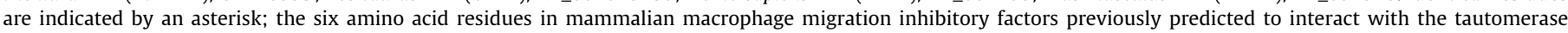

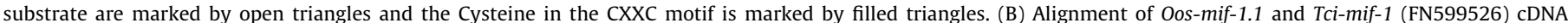

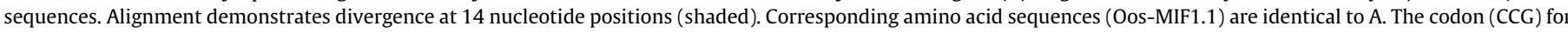

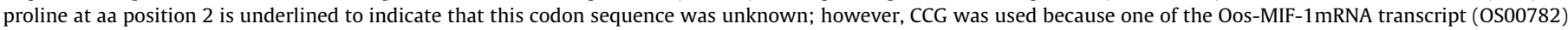

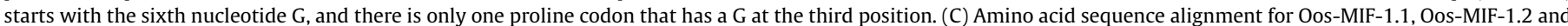

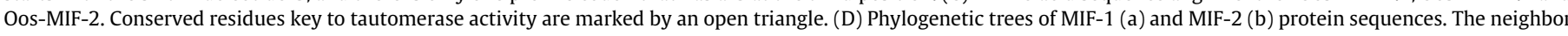

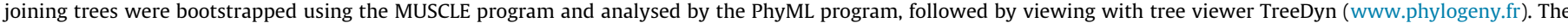

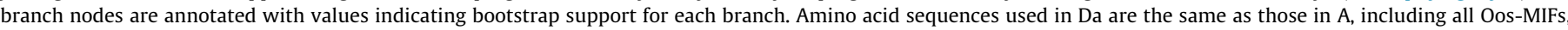

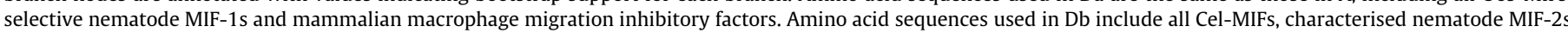

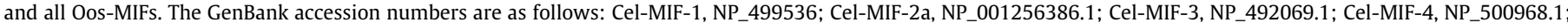
Bma-MIF-2, AAF91074; Asu-MIF-2, ADY48840; Oos-MIF-1.1, KJ427776; Oos-MIF-1.2, OS04085; Oos-MIF-2, Oost_isotig21269. 
C

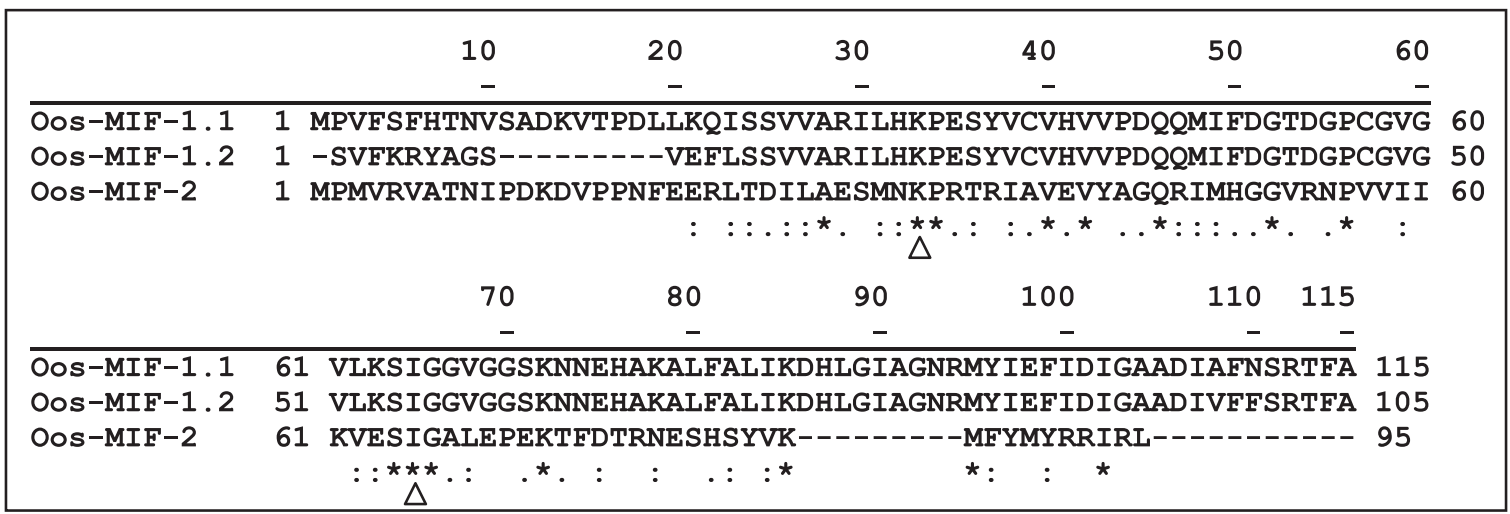

D
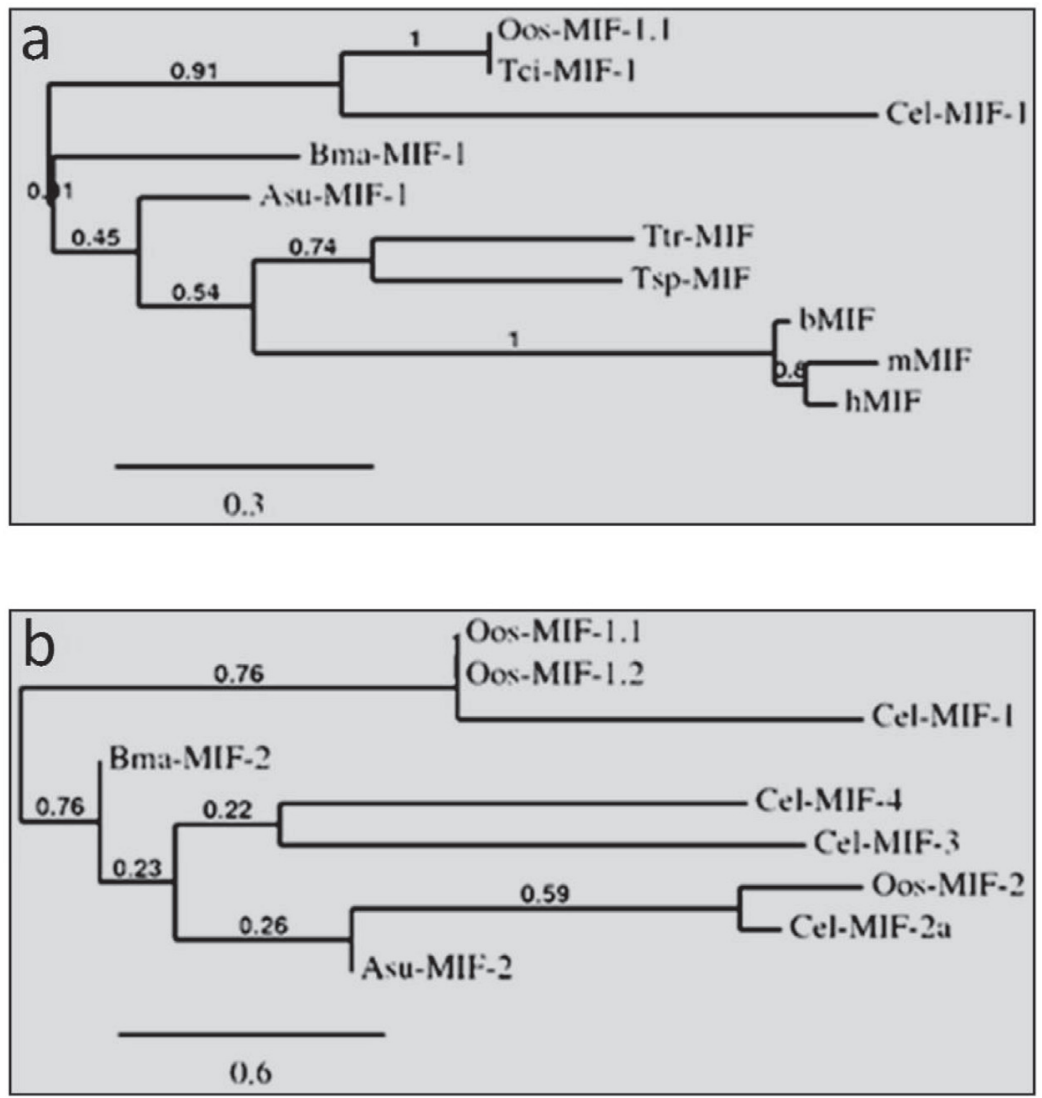

Fig. 1 (continued)

2.9. Regulation of glucocorticoid action and migration inhibition of bovine adherent peripheral blood mononuclear cells (aPBMC) by rOosMIF-1.1

The ability of rOos-MIF-1.1 to counter-regulate glucocorticoid action was tested as described by Roger et al. (2005). Bovine aPBMCs were isolated by culturing whole PBMC in 24-well plates for $24 \mathrm{~h}$ and removing the non-adherent cells. aPBMCs and human monocyte cells (U937, American Type Culture Collection (ATCC), Manassas, Virginia, USA) $\left(3 \times 10^{6}\right.$ cells/well in 24-well plate) in RPMI 1640 containing 10\% FBS, glutamine ( $25 \mathrm{mM}$ ) and gentamicin $(50 \mu \mathrm{g} / \mathrm{ml})$ (complete medium) were incubated with either dexamethasone $(1 \mathrm{nM})$ or dexamethasone plus various concentrations of rOos-MIF-1.1 (0, $1 \mathrm{ng}, 10 \mathrm{ng}$ or $100 \mathrm{ng} / \mathrm{ml})$ for $1 \mathrm{~h}$. Phorbol myristate acetate (PMA, $1 \mathrm{ng} / \mathrm{ml}$; Sigma) or PMA plus lipopolysaccharide (LPS, $100 \mathrm{ng} / \mathrm{ml}$; Sigma) was then added and incubated for an additional $4 \mathrm{~h}$. Total RNA was extracted using the Trizol reagent (Invitrogen) and subsequently treated with RNase-free DNase I (Invitrogen) to remove contaminating genomic DNA prior to realtime quantitative PCR (qPCR).

The inhibitory effect of rOo-MIF-1.1 on aPBMC migration was determined using the polycarbonate membrane-based trans-well chemotaxis inserts with $5 \mu \mathrm{m}$ pore size and $6.5 \mathrm{~mm}$ in diameter (Corning, Lowell, MA, USA), as previously reported (Nisbet et al., 2010). In brief, $700 \mu \mathrm{l}$ of the complete medium was added to wells (which served as the lower chamber) of a 24 -well plate prior to 
A

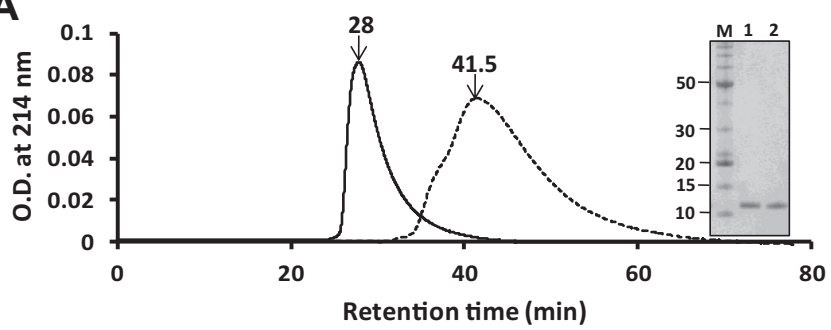

B

a

$123 \quad$ b

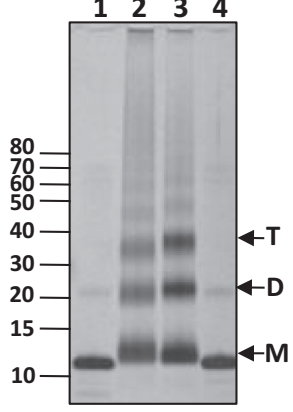

b

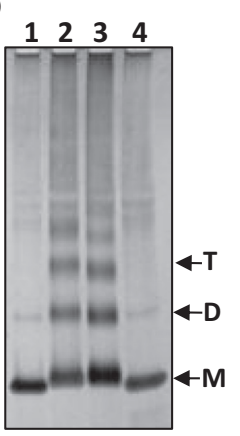

c
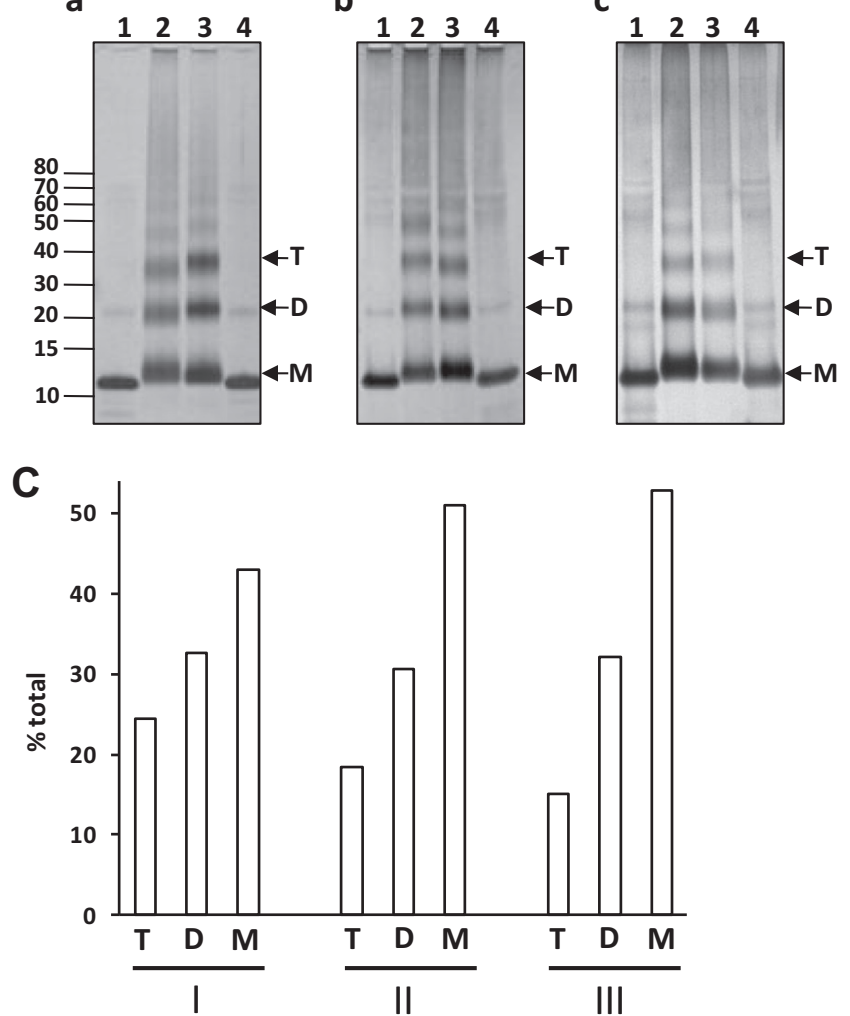

Fig. 2. Characterization of recombinant Ostertagia ostertagi macrophage migration inhibitory factor -1.1 (rOos-MIF-1.1) and its mutants by (A) SDS-PAGE and size exclusion chromatography (SEC)-HPLC, and (B) chemical cross-linking. (A) SECHPLC purification (chromatograph) and SDS-PAGE analysis (insert) of rOos-MIF-1.1 (solid line) and rOos-MIF-1.1P1G (dotted line). The peak retention times in min are indicated for both rOos-MIF-1.1 and rOos-MIF-1.1P1G. SDS-PAGE insert: $\mathrm{M}$, molecular weight markers; Lane 1, rOos-MIF-1.1; Lane 2, rOos-MIF-1.1P1G. (B) Silver staining analysis of cross-linked rOos-MIF-1.1 and its mutants separated on 4-12\% NuPAGE gels. (a) rOos-MIF-1.1; (b) rOos-MIF-1.1P1G; (c) rOos-MIF-1.1P1+P. A total of $2 \mu \mathrm{g} / \mathrm{ml}$ of rOos-MIF-1 in $1 \mathrm{ml}$ total volume was used in the cross-linking reactions. Lane 1 , protein fixed by $\mathrm{NaBH}_{4}$ without $1 \%$ glutaraldehyde; Lane 2, protein treated with $1 \%$ glutaraldehyde without $\mathrm{NaBH}_{4}$ fixation; Lane 3, protein treated with $1 \%$ glutaraldehyde followed by $\mathrm{NaBH}_{4}$ fixation; Lane 4 , untreated protein. The arrows indicate positions of monomers (M), dimers (D) and trimers (T). (C) Densitometric analysis of monomers, dimers and trimers of rOos-MIF-1.1 (I), rOos-MIF-1.1P1G (II) and rOos-MIF-1.1P1+P (III) determined by cross-linking assay from two independent experiments. \% total represents the percentage of monomers, dimers or trimers in the total of monomers, dimers and trimers detected.

placing inserts in the wells. aPMBCs $\left(10^{6}\right.$ cells per well $)$ in $100 \mu \mathrm{l}$ containing medium alone, $0.1 \mu \mathrm{g} / \mathrm{ml}$ of rOo-MIF-1.1, or $1.0 \mu \mathrm{g} / \mathrm{ml}$ of rOo-MIF-1.1 were then added to the inserts (which served as the upper chamber). Following incubation at $37{ }^{\circ} \mathrm{C}$ in the presence of $5 \% \mathrm{CO}_{2}$ for $4 \mathrm{~h}$, the inserts were rinsed gently three times with PBS (kept at RT), fixed in methanol at $-20^{\circ} \mathrm{C}$ for $1 \mathrm{~h}$ and air-dried overnight. The membrane was then removed, stained with Differential Quik Stain Kit (Modified Giemsa, Electron Microscopy Sciences (EMS), Hatfield, PA, USA) and mounted onto a glass slide.
A

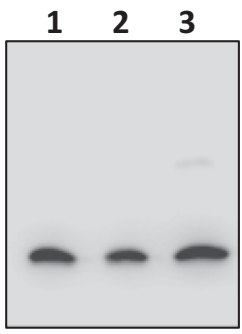

B
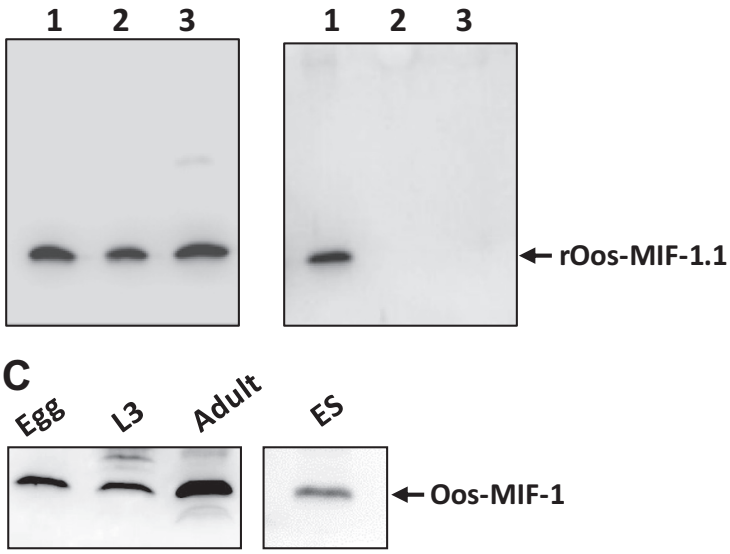

D

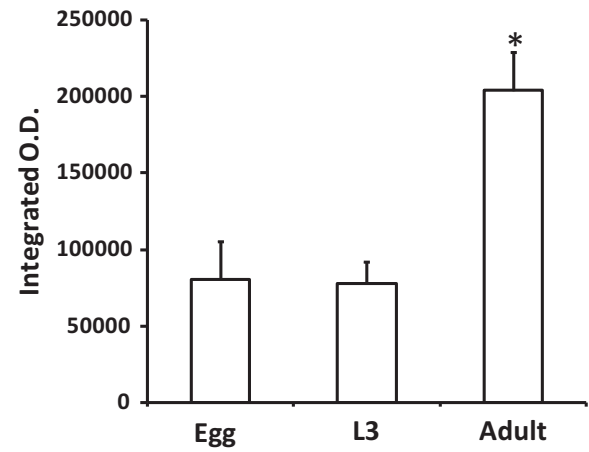

Fig. 3. Western blot analysis of (A) recombinant Ostertagia ostertagi macrophage migration inhibitory factor-1.1 (rOos-MIF-1.1) and its mutants, (B) cross-reactivity of anti-rOos-MIF-1.1 to recombinant Neospora caninum MIF (rNcMIF) and mouse macrophage migration inhibitory factor, and (C, D) native Oos-MIF-1 in 0 . ostertagi at various stages of the life cycle. (A) Western blot analysis of rOos-MIF-1.1 and its mutants $(0.1 \mu \mathrm{g} /$ lane $)$ using the sheep anti-rOos-MIF-1.1 antibody. Lane 1 , rOosMIF-1.1; Lane 2, rOos-MIF-1.1P1G; Lane 3, Oos-MIF-1.1P1+P. (B) Cross-reactivity of anti-rOos-MIF-1.1 to macrophage migration inhibitory factors $(0.1 \mu \mathrm{g} / \mathrm{lane})$ from other species. Lane 1, rOos-MIF-1.1; Lane 2, rNcMIF; Lane 3, mouse macrophage migration inhibitory factor. (C) Western blot analysis of native Oos-MIF-1. Egg, $O$. ostertagi embryonated egg homogenate; L3, homogenate of infective 0 . ostertagi L3s; Adult, lysate of $O$. ostertagi adult worms; ES, excretory/secretory (ES) product of 0 . ostertagi adult worms, which was concentrated from the culture medium using the trichloroacetic acid precipitation method. An equal amount of total protein $(7.8 \mu \mathrm{g})$ was loaded in each lane except for ES. The amount of Oos-MIF-1 in Egg, L3 and Adult is expressed as mean integrated O.D. \pm S.E.M. Data represent four independent experiments. ${ }^{*} P<0.01$.

Migrated cells in each membrane were counted under a microscope at $100 \times$ magnification.

\subsection{0. $q-P C R$ analysis of cytokine gene expression}

Total RNA ( $1 \mu \mathrm{g})$ was used to synthesise cDNA with an oligo $\mathrm{d}(\mathrm{T})_{18}$ primer using a M-MuLV Reverse Transcriptase Kit (Promega). qPCR was performed using SsoAdvanced SYBR Green Supermix (Bio-Rad, Hercules, California, USA) and the Bio-Rad CFX96 Realtime system (Bio-Rad). cDNA (100 ng total RNA equivalent) was added to a $20 \mu \mathrm{l}$ reaction with bovine or human cytokine primers reported previously (Leutenegger et al., 2000; Roger et al., 2005; Thacker et al., 2007). The actin gene was used to normalise loading. The bovine cytokine and actin q-PCR was performed using these conditions: $95^{\circ} \mathrm{C}$ for $3 \mathrm{~min}$ followed by 40 cycles of $15 \mathrm{~s}$ denaturation at $95{ }^{\circ} \mathrm{C}$ and $1 \mathrm{~min}$ annealing at $60^{\circ} \mathrm{C}$. The human cytokine q-PCR was conducted using the following conditions: $95^{\circ} \mathrm{C}$ for $3 \mathrm{~min}$ followed by 45 cycles of $15 \mathrm{~s}$ at $95^{\circ} \mathrm{C}, 30 \mathrm{~s}$ at $62^{\circ} \mathrm{C}$, and $15 \mathrm{~s}$ at $74^{\circ} \mathrm{C}$. Data were analysed with the $2^{-\Delta \Delta \mathrm{Ct}}$ method as described previously (Livak and Schmittgen, 2001). 

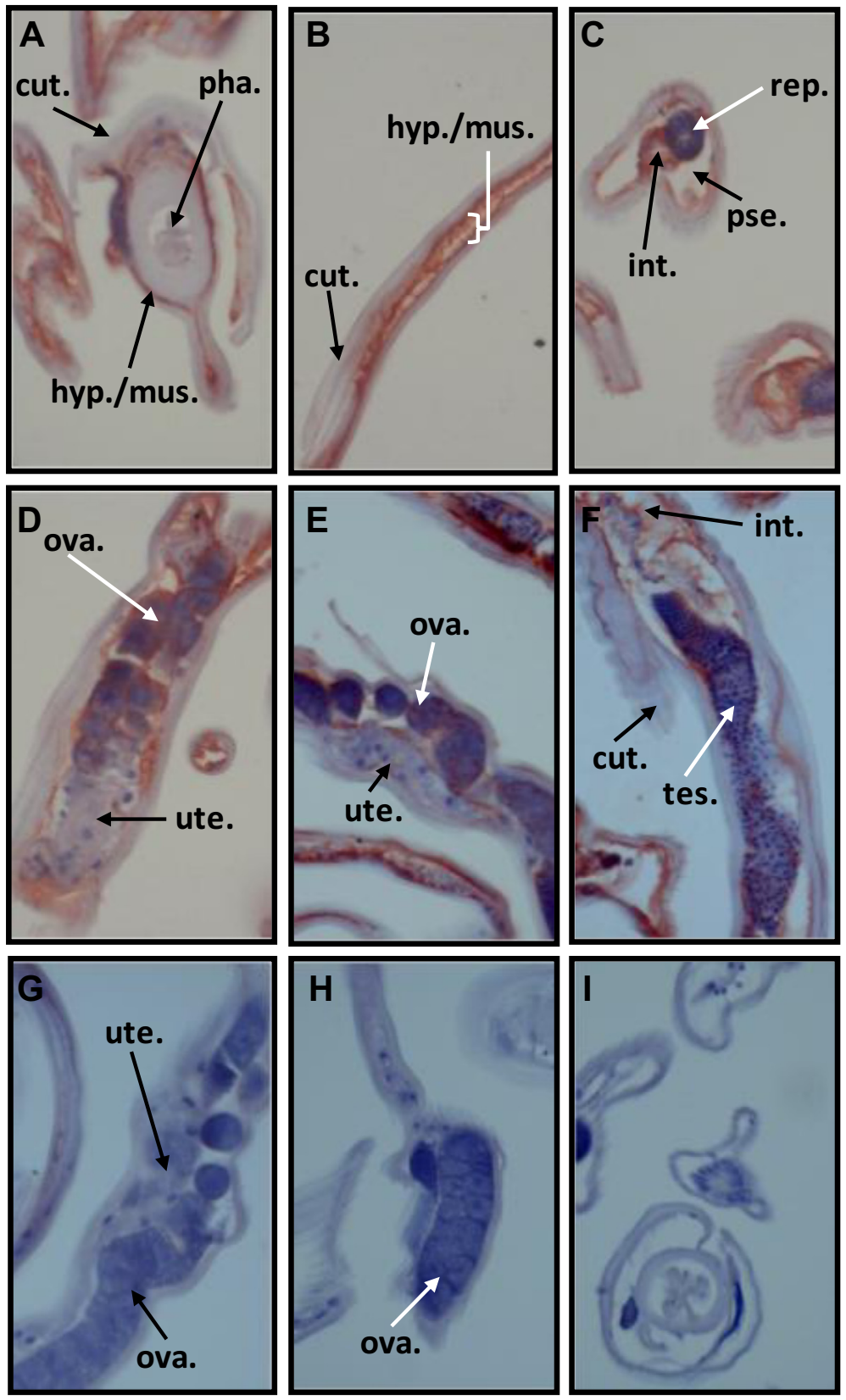

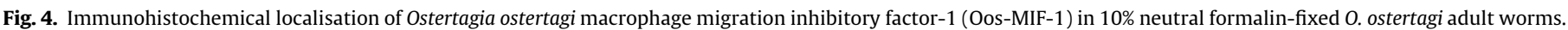

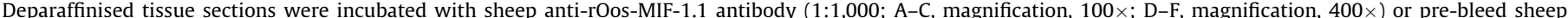

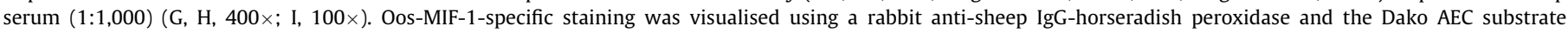

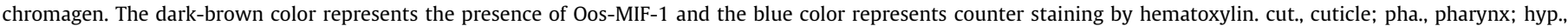
hypodermis; mus., muscle; rep., reproductive tract; int., intestine; pse., pseudocelom; ova., ovary; ute., uterus; tes., testis.

\subsection{Statistical analysis}

Data were analysed by GraphPad InStat software (La Jolla, CA, USA) using one-way ANOVA with Student-Newman-Keuls Multiple Comparisons Test. Unless otherwise indicated, all data are presented as mean \pm S.E.M. A probability of less than 0.05 was considered statistically significant.

\section{Results}

\subsection{Oos-MIF genes and proteins}

There are two cDNA sequences (BQ457770, BQ457911), one EST sequence (OS00782) and two mRNA transcripts (Oost_isotig14764,
Oost_isotig14765), coding for an Oos-MIF, all of which are partial sequences, lacking the $5^{\prime}$ terminus. The cDNA 0500782 is the longest sequence, missing only five nucleotides at the $5^{\prime}$ terminus compared with Tci-mif-1 cDNA (CBI68362A) of the sister parasite $T$. circumcincta, whose nucleotide sequence is over $90 \%$ similar to that of this Oos-mif (Nisbet et al., 2010). Inasmuch as all MIFs identified thus far have a conserved Pro at the second predicted amino acid (aa) position, it was reasoned that the first two aas for OosMIF are Met and Pro. Methionine is encoded by the unique codon of ATG. We chose CCG as the Pro codon because the first base of cDNA OS00782 is a G. Thus, the 5' sequence of ATGCCGGTTTTCTC of Oos-mif was used to synthesise the $5^{\prime}$ primer. A full length Oos-mif cDNA (348 bp) was amplified from 0 . ostertagi adult worm mRNA by reverse transcription (RT)-PCR and its deduced 115 aa 


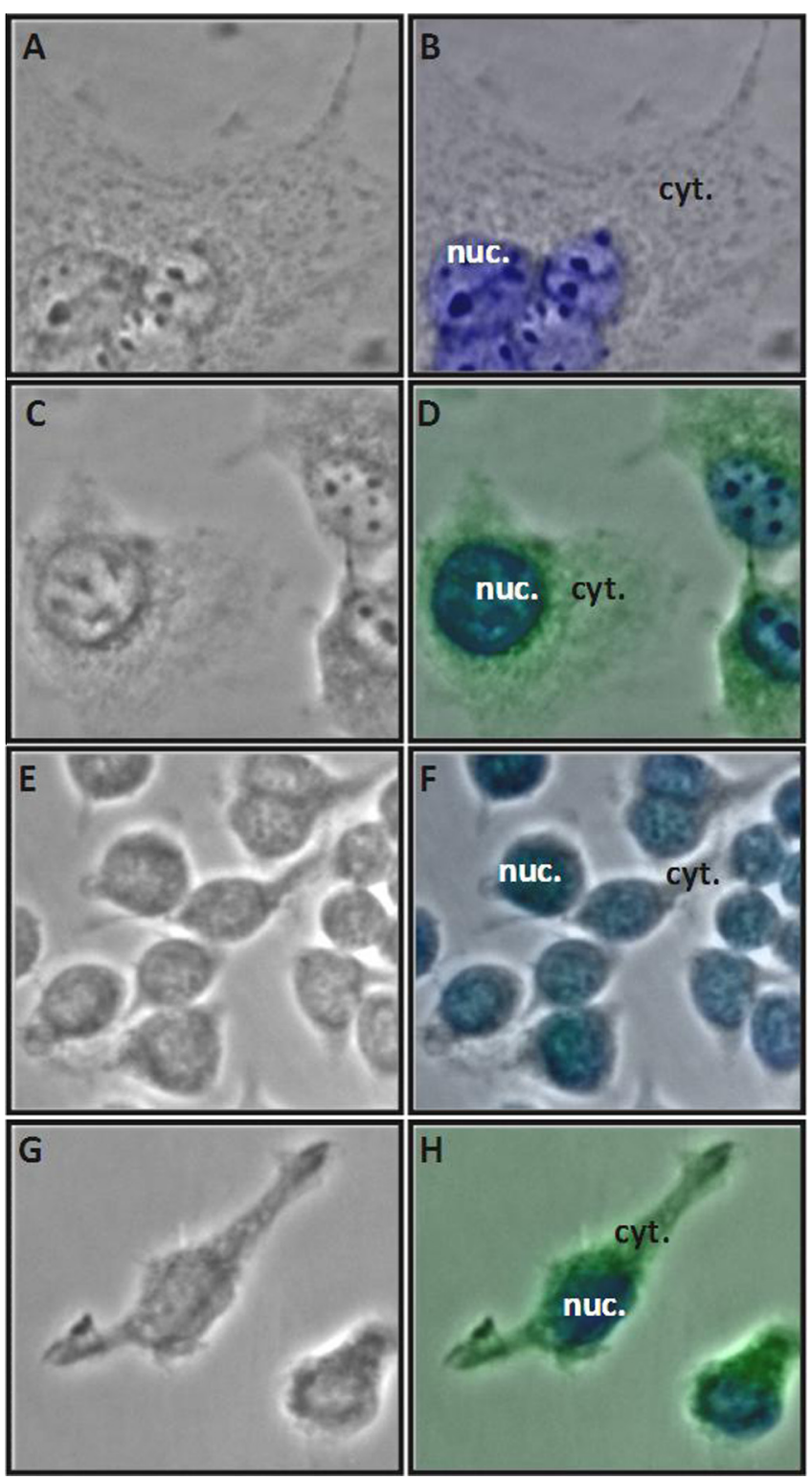

Fig. 5. Internalisation of recombinant Ostertagia ostertagi macrophage migration inhibitory factor -1.1 (rOos-MIF-1.1) by macrophages. Bovine (BoMac, A-D) and murine (RAW264.7, E-H) macrophage cell lines were pre-incubated with $10 \mu \mathrm{g} / \mathrm{ml}$ of rOos-MIF-1.1 overnight and fixed with methanol/acetone at $-20^{\circ} \mathrm{C}$ for $20 \mathrm{~min}$ followed by immunostaining with sheep anti-rOos-MIF-1.1 antibodies. (A, C, E and $\mathrm{G}$ ) Bright field/phase images. (B, D, F and H) Overlay of the matching bright field/ phase and fluorescence staining images. (A, B) BoMac and (E, F) RAW247.6 cells were incubated with rOos-MIF-1.1 followed by staining with pre-immune sera (1:800), rabbit anti-sheep IgG-DyLight 488 and DAPI. (C, D) BoMac and (G, H) RAW247.6, cells were incubated with rOos-MIF-1.1 followed by staining with sheep anti-rOos-MIF-1.1 antibody (1:800) and by detection with rabbit anti-sheep IgGDyLight 488 and DAPI. nuc., nucleus; cyt., cytoplasm. Controls also included cells incubated without rOoMIF1 and stained with rabbit anti-sheep IgG-DyLight 488 alone or sheep anti-OoMIF antibody $(1: 800)$ followed by detection by rabbit antisheep IgG-DyLight 488 and DAPI. No specific staining was seen in controls. Magnification, $400 \times$

sequence was identical to that of Tci-MIF-1, although this Oos-mif gene differs from that of Tci-mif-1 by 14 nucleotides, all of which are synonymous (Fig. 1B). Alignment of aa sequences from selected mammals, parasitic nematodes and a free-living nematode indicates that the Oos-MIF characterised in this study shares $40-42 \%$ identity with mammalian MIFs and $44-55 \%$ with the nematode MIFs (Fig. 1A). Phylogenetic analysis revealed that this Oos-MIF should belong to the MIF1 family, based on its similarity to $B$. malayi (Bma)-MIF-1 (AAB60943) and C. elegans (Cel)-MIF-1 (NP_499536) (Figs. 1A, D). Furthermore, an Oos-MIF-1 isoform (encoded by $\mathbf{0 S 0 4 0 8 5}$ and BQ457552) is also present, which shares an overall sequence identity of $93 \%$ with the Oos-MIF- 1 studied herein (Fig. 1C, Db). Therefore, we designated the Oos-MIF-1 cloned and characterised in the present study as Oos-MIF-1.1 (Fig. 1Da), and the Oos-MIF-1 encoded by OS04085 and BQ457552 as Oos-MIF1.2 (Fig. 1Db). Oos-MIF-1.2 is identical to Oos-MIF-1.1 from aa 23 to 115 except for aa residues 108 and 110 , and has a deletion between aa 11 and 19 (Fig. 1C). Importantly, Oos-MIF-1.2 appears to lack a Pro at position 1; however, this feature needs to be further confirmed when the full coding sequence for Oos-MIF-1.2 becomes available (Fig. 1C). Additional analysis demonstrated that there is an Oos-MIF-2 (Oost_isotig21269), closely related to Cel-MIF-2, Bma-MIF-2, and Asu-MIF-2 (Figs. 1C, Db). Oos-MIF-2 is only 95 aa in length with deletions at aa 86-94 and aa 105-115 relative to that of Oos-MIF-1.1, and shares a limited aa sequence identity of $20 \%$ and $15.8 \%$ with Oos-MIF-1.1 and Oos-MIF-1.2, respectively. However, Oos-MIF-2 is $45.3 \%$ identical to Cel-MIF-2a (Fig. 1C, Db).

The translation initiating Met1 is removed from native MIF by proteolytic processing, exposing Pro as the first aa residue. Cleavage of Met1 also occurs in recombinant MIF expressed in E. coli (Bernhagen et al., 1994; Sun et al., 1996b). Thus, the first aa of Oos-MIF-1.1 is Pro1 (Fig. 1A). The calculated Oos-MIF-1.1 molecular mass is $12.2 \mathrm{kDa}$ with a predicted pI of 6.59 . Oos-MIF-1.1 does not appear to contain a conventional signal peptide (SignalP 4.0, http://www.cbs.dtu.dk/services/SignalP-4.1/). Similar to most nematode MIFs, Oos-MIF-1.1 and Oos-MIF-1.2 possess four (Pro1, Lys32, Ile64 and Tyr95) out of six of the critical aas for tautomerase activity in mammalian MIF (Fig. 1A). Oos-MIF-2 only retains Lys32 and Ile64 (Fig. 1B). The Cys57XXCys60 motif which is responsible for mediating the catalytic oxidoreductase activity in mammalian MIFs is absent from all Oos-MIFs, only retaining Cys57 in Oos-MIF-1s (Fig. 1A).

\subsection{Expression, purification and chemical cross-linking of rOos-MIF- 1.1 and its mutants}

Soluble rOos-MIF-1s were expressed in E. coli BL21 (DE3) at $30{ }^{\circ} \mathrm{C}$ in the presence of $1 \mathrm{mM}$ IPTG and purified to $95-99 \%$ homogeneity by size exclusion chromatography (SEC)-HPLC. rOos-MIF1.1, rOos-MIF-1.1P1G and rOos-MIF-1.1P1+P exhibited a similar molecular mass of approximately $12 \mathrm{kDa}$ (Fig. 2A, B); however, rOos-MIF-1.1P1G had an average chromatographic retention time of $41.5 \mathrm{~min}$ which is $13 \mathrm{~min}$ longer than that for rOos-MIF-1.1 (28 min) (Fig. 2A). rOos-MIF-1.1P1+P had a retention time similar to that of rOos-MIF-1.1 (data not shown). Mammalian MIFs likely exist as a mixture of monomers, dimers and trimers, although equilibrium density sedimentation studies are consistent with a predominant trimer form (Mischke et al., 1998; Philo et al., 2004). To characterise the oligomerisation state of rOos-MIF-1.1, purified proteins were cross-linked and analysed under reducing conditions (Fig. 2B). The results showed that in the absence of cross-linking, rOos-MIF-1.1 exists predominantly as a monomer. Following cross-linking, rOos-MIF-1.1 and its mutants exhibited three main forms: monomers, dimers and trimers, with the monomer being the predominant form (Fig. 2B, C). Some minor products of higher oligomerisation also were detected by this method (Fig. 2B). Glutaraldehyde slightly increased the amount of dimers and trimers in rOos-MIF-1.1 and rOos-MIF-1.1P1G, but appeared to decrease oligomerisation in rOos-MIF-1.1P1+P (Fig. 2B). Overall, rOos-MIF-1.1 had the highest level of trimers, whereas rOos-MIF-1.1P1G and rOos-MIF-1.1P1+P had slightly 

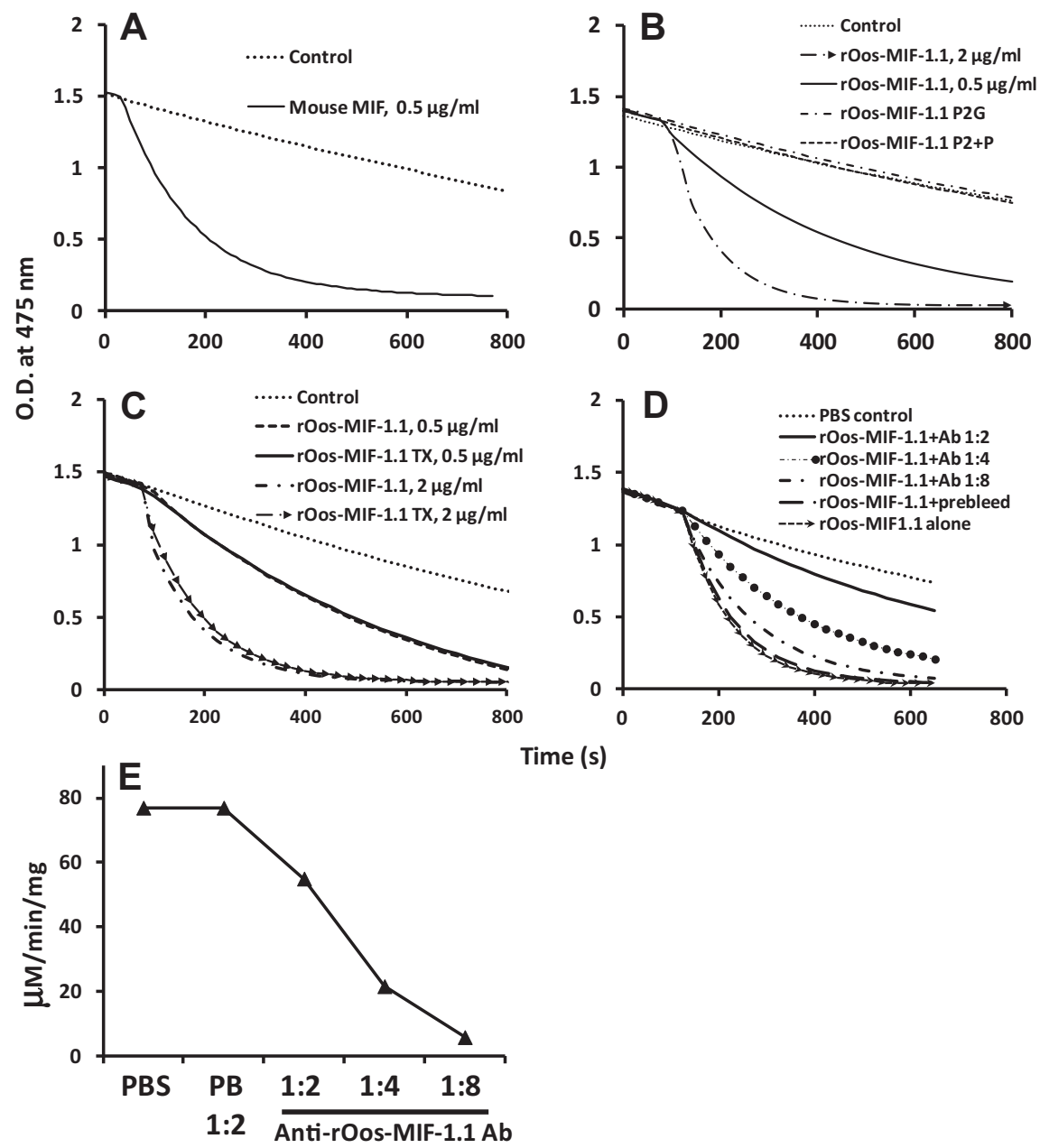

Time (s)

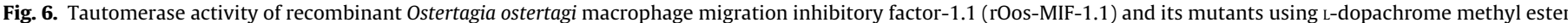

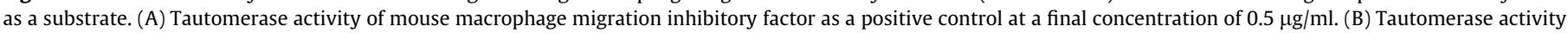

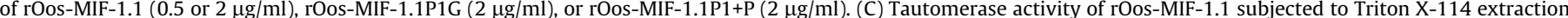

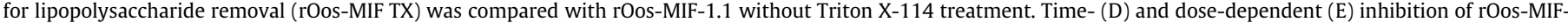

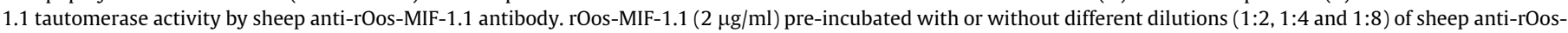

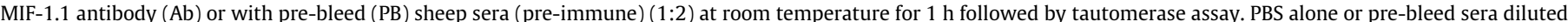
in PBS (1:2) was used as the negative control throughout the experiments. The data represent three independent experiments.

lower levels of trimers and concomitantly higher levels of monomers (Fig. 2C).

\subsection{Stage-specific expression of Oos-MIF-1}

A sheep-anti-rOos-MIF-1.1 antibody recognised SEC-HPLCpurified rOos-MIF-1.1 (Fig. 3A, B, Lane 1), rOos-MIF-1.1P1G (Fig. 3A, Lane 2) and rOos-MIF-1.1P1+P (Fig. 3A, Lane 3) as single bands of $\sim 12 \mathrm{kDa}$. This antibody is specific for Oos-MIF-1 and corresponding mutants because it lacked cross-reactivity with a protozoan MIF (recombinant N. caninum MIF) (Qu et al., 2013) or a mammalian MIF (recombinant mouse MIF; R\&D Inc.) (Fig. 3B, Lanes 2, 3). Oos-MIF-1 was detectable in lysates of 0 . ostertagi embryonated eggs, infective L3s, and adult worms (Fig. 3C). Oos-MIF-1 was clearly detectable in 0 . ostertagi adult worm secretory/excretory (ES) product prepared at $37^{\circ} \mathrm{C}$ (Fig. 3C), but not in that prepared at $4{ }^{\circ} \mathrm{C}$ (data not shown). Oos-MIF-1 level was higher $(P<0.01)$ in adult worms than in embryonated eggs and L3s (Fig. 3D), when compared using equal quantities of crude proteins prepared from each stage of the parasite. It was difficult to estimate the concentration of total ES proteins used due to the limited quantity available; consequently, Oos-MIF-1 in adult ES protein was not compared. The pre-bleed sera were used as negative controls and no proteins were detected by these sera under similar dilutions (data not shown).

\subsection{Immunolocalisation of Oos-MIF-1}

Oos-MIF-1 was primarily localised to the hypodermis/muscle layer (Fig. 4A, B), intestine (Fig. 4C, F) and reproductive tract (Fig. 4C-F) of adult worms. Within the reproductive tract, OosMIF-1 appeared to be associated with eggs/embryonated eggs in the ovary/uterus and unidentified cells/tissues in the uterus and testes (Fig. 4D-F). Oos-MIF-1 was not detected in cuticles and pharynx (Fig. 4A, B, F). To determine whether rOos-MIF-1.1 was taken up and internalised by macrophages, bovine (Fig. 5A-D) and mouse (Fig. 5E-H) macrophage cell lines were pre-incubated overnight with or without $10 \mu \mathrm{g} / \mathrm{ml}$ of rOos-MIF-1.1. Staining was not detected in cells incubated with rOos-MIF-1.1 and stained by secondary antibody alone (data not shown) or pre-immune sera (Fig. 5B, F), or in cells incubated with medium alone and stained with immune or pre-immune sera (data not shown). rOos-MIF1.1 was detected specifically in the cytoplasm of permeabilised, bovine (Fig. 5D) and murine (Fig. 5H) macrophage cell lines preincubated with rOos-MIF-1.1. 


\section{5. rOos-MIF-1.1 exhibits tautomerase activity}

Recombinant mouse MIF used as a positive control in the tautomerase assay demonstrated tautomerase activity of $250 \mu \mathrm{mol} /$ $\mathrm{min} / \mathrm{mg}$ (Fig. 6A). The tautomerase activity of rOos-MIF-1.1 was $84.3 \mu \mathrm{mol} / \mathrm{min} / \mathrm{mg}$ at $0.5 \mu \mathrm{g} / \mathrm{ml}$ and $90.5 \mu \mathrm{mol} / \mathrm{min} / \mathrm{mg}$ at $2 \mu \mathrm{g} /$ $\mathrm{ml}$ (Fig. 6B). rOos-MIF-1.1 tautomerase activity appeared to be nearly three-fold lower than that of mouse MIF, when compared at the $0.5 \mu \mathrm{g} / \mathrm{ml}$ of protein level (Fig. 6A, B). Both rOos-MIF1.1P1G and rOos-MIF-1.1P1+P mutants showed no detectable tautomerase activities (Fig. 6B). Since rOos-MIF-1.1 was treated with Triton X-114 to remove endotoxin, experiments were performed to determine whether this treatment affected the tautomerase activity. As shown in Fig. 6C, Triton X-114-treated rOos-MIF-1.1 at $0.5 \mu \mathrm{g} / \mathrm{ml}$ and $2 \mu \mathrm{g} / \mathrm{ml}$ concentrations had tautomerase activities of $92.8 \mu \mathrm{mol} / \mathrm{min} / \mathrm{mg}$ and $98.5 \mu \mathrm{mol} / \mathrm{min} / \mathrm{mg}$, respectively, which were comparable with those of Triton X-114 non-treated rOos-MIF-1.1 (Fig. 6B). The mouse MIF tautomerase activity decreased from 315 to $109 \mu \mathrm{mol} / \mathrm{min} / \mathrm{mg}$, a reduction of $65 \%$, in the presence of $400 \mu \mathrm{M}$ ISO- 1 which is a specific inhibitor of the mammalian MIFs (Al-Abed et al., 2005). The inhibitory effect of ISO-1 on rOos-MIF-1.1 tautomerase activity was only $32.4 \pm 7.7 \%$ (four replicates), a decrease from $100.8 \pm 10.3$ to $66.5 \pm 5.8 \mu \mathrm{mol} / \mathrm{min} / \mathrm{mg}$. The sheep anti-rOos-MIF-1.1 antibody was also tested for the inhibition of tautomerase activity of rOos-MIF-1.1. This antibody inhibited rOos-MIF-1.1 tautomerase activity in a dose-dependent manner (Fig. 5D, E). PBS or pre-immune sera had no effect on rOos-MIF-1.1 activity (Fig. 6E).

\section{6. rOos-MIF-1.1 competes with rhMIF for binding to human CD74}

Similar to rhMIF, rOos-MIF-1.1 competed with biotinylated rhMIF for binding to the human MIF receptor ectodomain (soluble

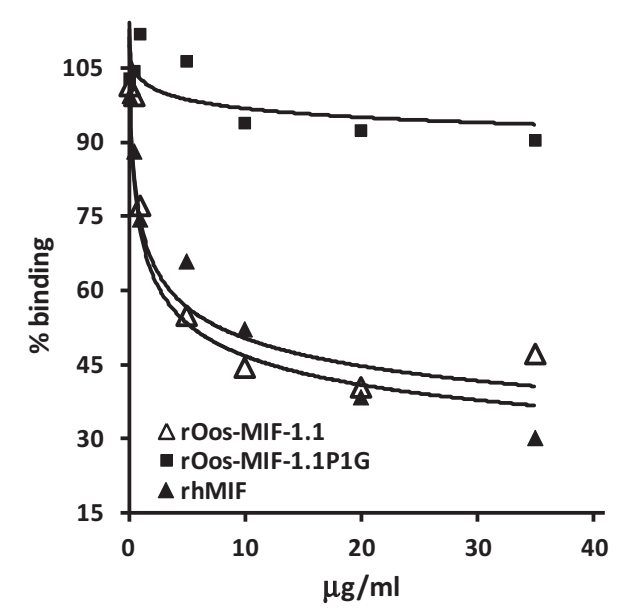

Fig. 7. Competitive binding of recombinant Ostertagia ostertagi macrophage migration inhibitory factor -1.1 (rOos-MIF-1.1) and mutant rOos-MIF-1.1P1G to the human MIF receptor ectodomain (soluble CD74) using an in vitro capture assay. Purified recombinant human macrophage migration inhibitory factor (rhMIF, filled triangle), rOos-MIF-1.1 (open triangle) or rOos-MIF-1.1P1G (filled square) ranging from 0.5 to $70 \mu \mathrm{g} / \mathrm{ml}$ were used to compete with biotinylated $\operatorname{rhMIF}(2.3 \mu \mathrm{g} / \mathrm{ml})$ for the human macrophage migration inhibitory factor receptor ectodomain which was coated on the plate. Percentage binding is expressed as (test macrophage migration inhibitory factor binding O.D. - background O.D.)/(total binding O.D. - background O.D.) $\times 100$, where the wells for test macrophage migration inhibitory factor binding contained a fixed concentration of biotinylated rhMIF and different concentrations of test macrophage migration inhibitory factor, wells for total binding contained biotinylated rhMIF alone, and the wells for background reading contained medium or unlabeled test macrophage migration inhibitory factor only. Each data point represents the mean percentage of binding with a pooled S.E.M. of $4.8 \%$ from two independent experiments.
CD74 ${ }^{73-232}$ ) in a dose-dependent manner (Fig. 7). rOos-MIF1.1P1G, which had Pro at position 2 mutated to Gly, had very low binding to the human MIF receptor (Fig. 7).

\subsection{Regulation of glucocorticoid effect and inhibition of aPBMC migration by rOos-MIF-1.1}

rOos-MIF-1.1, at all concentrations tested, restored dexamethasone-suppressed TNF $\alpha$ and IL-8 induction by LPS in U937 cells (Fig. 8Aa, b). Similarly, rOos-MIF-1.1 reversed the dexamethasone-suppressed TNF $\alpha$ induction by LPS in bovine aPBMC at the dose of $10 \mathrm{ng} / \mathrm{ml}$ (Fig. 8Ac), but had no apparent effect on the IL8 response (Fig. 8Ad). rOos-MIF-1.1 at $1 \mu \mathrm{g} / \mathrm{ml}$, but not $0.1 \mu \mathrm{g} / \mathrm{ml}$, inhibited random migration of bovine aPBMCs compared with medium alone (Fig. 8B).

\section{Discussion}

MIF is a conserved protein throughout the plant and animal kingdoms as shown by much research in the past decades (Lolis and Bucala, 2003) and recent genome sequencing (Tabata et al., 2000; Schnable et al., 2009). MIF also has been described in nematodes and protozoa, some of which are animal and/or human parasites (Vermeire et al., 2008). While information for the definitive functions of mammalian MIFs is progressively accumulating, the functions of MIFs from the free-living and parasitic nematodes are largely unknown. The present study characterised a MIF ortho$\log$, Oos-MIF-1.1, from the cattle abomasal parasite, 0 . ostertagi. From analysis of all available Oos-MIF transcript sequences, we found that there are at least three distinct Oos-MIF transcripts, with two (Oos-MIF-1.1 and Oos-MIF-1.2) belonging to the MIF-1 family and one (Oos-MIF-2) to the MIF-2 family based on sequence similarities with the Cel-MIFs. Since Oos-MIF-1.1 and Oos-MIF-1.2 are highly conserved, we speculate they share similar immunologic epitopes, as well as similar bio-activities given the similarities in their primary aa sequences. The biological activities of the OosMIF-2 are currently unknown and await further investigation. It is worth noting that since the C-terminus (residues 105-114) is crucial to the catalytic activity and stability of human MIF (El-Turk et al., 2008), the biological properties of Oos-MIF-2 with an absent C-terminus are difficult to predict. In addition, Oos-MIF-1.1 was selected for characterisation in the present study because Oos-MIF1.2 may be missing the catalytic Pro1 residue and Oos-MIF-2 lacks the C-terminus considered essential for stable oligomerisation. We believe the present study is the first to characterise the Oos-MIF isoforms based on cDNA and mRNA sequences available.

Oos-MIF-1.1 possesses four of six aa residues critical for the tautomerase catalytic activity, including Pro1, Lys32, Ile64 and Tyr95 (Bendrat et al., 1997). Similar to the findings in N. caninum MIF reported previously (Qu et al., 2013), a point mutation at Pro1 led to prolonged retention time for rOos-MIF-1.1P1G on SEC-HPLC and reduced oligomerisation. Intrigued by this observation, we further determined whether addition of a Pro2 between Pro1 and Val3 would change the chromatographic profile. The results indicate that addition of Pro2 did not alter its retention time on SEC-HPLC nor its mobility on SDS-PAGE. However, oligomerisation as shown by the cross-linking experiments was reduced in the absence of Pro1 or in the presence of Pro2. This is consistent with recent reports that Pro is essential for protein configuration and oligomerisation (Bernacchi et al., 2011; Shukla et al., 2012).

The Cys57XXCys60 motif is absent from all Oos-MIFs, thus the lack of oxidoreductase activity by rOos-MIF-1.1 was not confirmed in the present study and remains to be empirically elucidated. rOos-MIF-1.1 was fully functional as a tautomerase, although it was less active than mouse MIF. rOos-MIF-1.1 also appears to be 


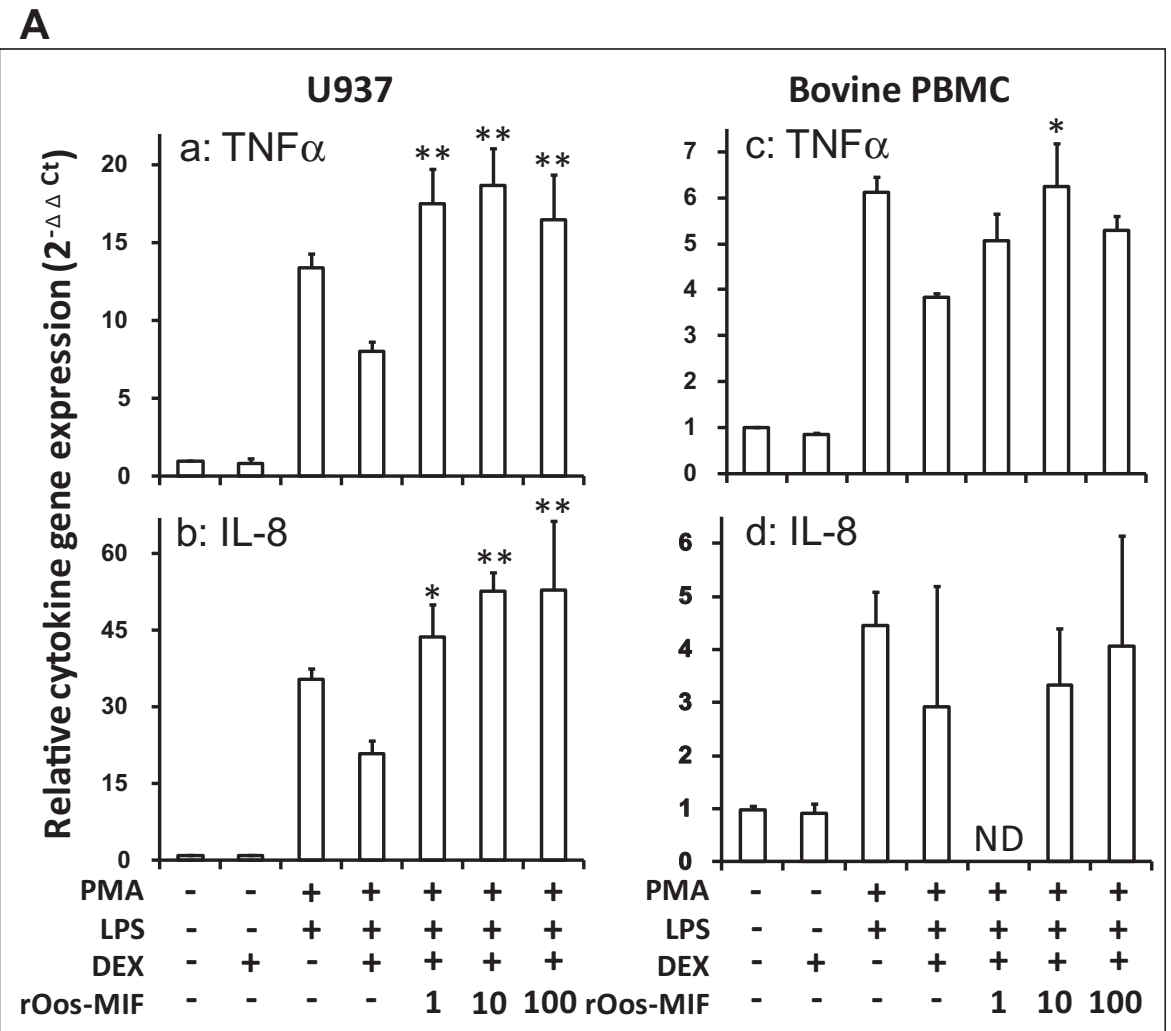

B

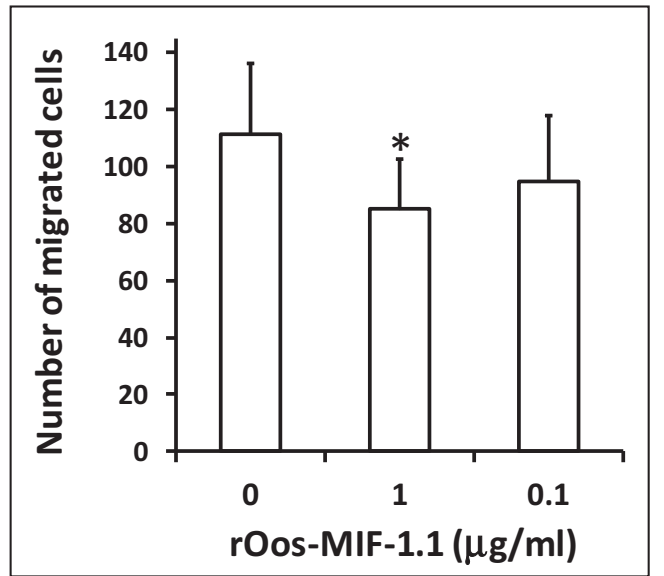

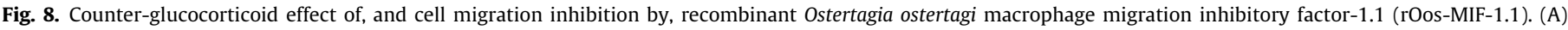

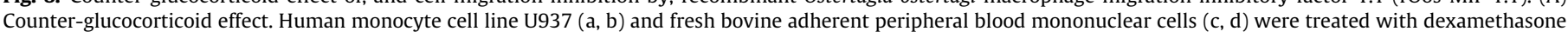

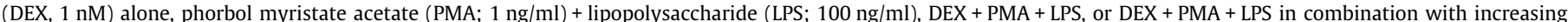

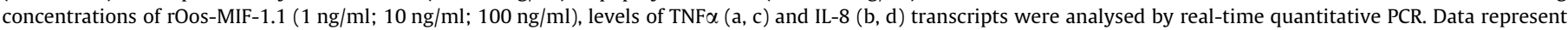

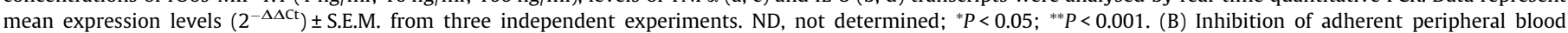

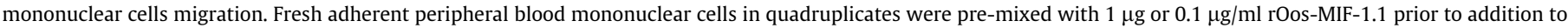

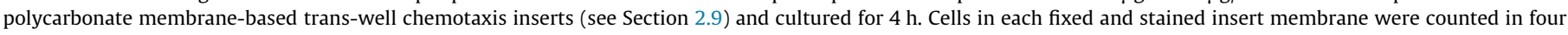
viewing fields. Results represent mean \pm S.D. of three independent experiments. ${ }^{*} P<0.05$.

much less active than other nematode MIFs catalysing the same tautomerase substrate (Tan et al., 2001; Cho et al., 2007); however, it is more active than almost all of the protozoan MIFs with respect to tautomerase activity (Augustijn et al., 2007; Richardson et al., 2009; Qu et al., 2013; Sommerville et al., 2013). Both the absence of Pro1 and presence of Pro2 rendered Oos-MIF-1.1 non-functional, suggesting that Pro1 is critical in its structure and tautomerase activities, but not the two aas (Asn97 and Val106 that are absent from Oos-MIF-1.1) that are critical to that of the mammalian MIFs. Intriguingly, Pro1, Lys32, Ile64 and Tyr95 are also conserved between mammalian MIFs and Neospora MIF, but it is apparent that this conservation is not sufficient for Neospora MIF to be active as a tautomerase (Qu et al., 2013). The results suggest that enzymatic centers of the mammalian MIFs and those of the nematodes are structurally different. Crystal structures of MIFs indicate that the trimer is the functional form of MIF (Sun et al., 1996b). The reduction in tautomerase activity in rOos-MIF-1.1 mutants may also be related to reduced trimer formation as shown in the present study or the lack of an appropriate catalytic pocket (Lubetsky et al., 1999). Interestingly, the mammalian MIF-specific inhibitor, ISO-1(Lubetsky et al., 2002), was only partially effective in inhibiting rOos-MIF-1.1 tautomerase activity, while our sheep 
anti-rOos-MIF-1.1 antibody was able to completely abrogate the rOos-MIF-1.1 tautomerase activity. These results indicate again that the catalytic centers of the mammalian MIFs and that of Oos-MIF-1 may be structurally different, and antibody binding is a powerful tool to study the tautomerase-related activities.

As shown, Oos-MIF-1.1 and Oos-MIF-1.2 are highly similar but different from the Oos-MIF-2; therefore, the anti-rOos-MIF-1.1 antibody produced in this research likely recognises both OosMIF-1.1 and 1.2 in Western blotting and immunohistochemistry but not Oos-MIF-2. For this reason, Oos-MIF detected in the parasite by this antibody is referred to as Oos-MIF-1 collectively. OosMIF-1 is present at all stages of development examined, with the highest levels expressed at the adult stage. These results are different from those of Tci-MIF-1, where Tci-mif-1 transcript and TciMIF-1 appear to be higher in the egg and/or L3 than in the adult worm (Nisbet et al., 2010). In addition, this pattern of expression of Oos-MIF-1 also seems to differ from those of the Cel-mif-2 and Cel-mif-3 genes, in which these genes are highly expressed in the dauer larvae stage (Marson et al., 2001). This study clearly showed that Oos-MIF-1 is also present at low levels in adult ES product and that it is only secreted at physiological temperatures relative to ES protein prepared at $4{ }^{\circ} \mathrm{C}$, suggesting that ES Oos-MIF-1 is actively released and not the result of leakage from live and/or dead worms. However, Tci-MIF-1 protein was not detected in the ES products of T. circumcincta larvae or adult worms (Smith et al., 2009; Nisbet et al., 2010). Due to the lack of a signal peptide, Oos-MIF-1 detected in the ES preparation may be secreted using non-classical pathways.

A recent report on 0 . ostertagi transcriptomes indicates that Ostertagia MIF-like transcripts (as clustered under OS00282.cl) are more abundant in L4s (10 transcripts) than in L3s (one transcript) (Abubucker et al., 2009). However, the OS00282.cl cluster contains seven distinct sequences (http://www.nematode.net), four of which belong to the $40 \mathrm{~S}$ ribosomal protein S17 family, one that is not translatable, and two (OS0782 and OS04085) that coincide with the Oos-MIF-1.1 and Oos-MIF-1.2 identified here, respectively. Oos-MIF-1 was not determined in L4s in the present study, and additional research is needed to show the differential expression of this molecule in L4s in comparison to other stages.

Oos-MIF-1 was localised to the hypodermis/muscle layer, reproductive tract and intestine of the adult worm, which is consistent with the presence of Oos-MIF-1 in ES products and worm lysate. This pattern of distribution in the adult worm is consistent with that in T. circumcincta (Nisbet et al., 2010), B. malayi and C. elegans (Pastrana et al., 1998; Marson et al., 2001), which suggests a common role for this molecule in worm development. Furthermore, following incubation of the rOos-MIF-1.1 with macrophages, this recombinant protein was specifically localised to the cytoplasm of the permeabilised macrophages, suggesting that rOos-MIF-1.1 was internalised by those cells. This interaction of Oos-MIF-1.1 with host immune cells was further verified by its specific binding to human CD74, a MIF receptor (Leng et al., 2003). This result demonstrates that the Oos-MIF-1.1 secreted by 0 . ostertagi in the abomasal tissue can interact with host immune cells and in so doing regulate local immunity. Indeed, the present study on Oos-MIF-1 and the previous report on Tci-MIF-1 (Nisbet et al., 2010) demonstrated the immunoregulatory functions of nematode-derived MIF in cytokine production and monocyte migration, respectively. Recently, this same group has demonstrated an efficacious cocktail vaccine against $T$. circumcincta, which contained recombinant Tci-MIF-1 as one of the multiple recombinant proteins in the vaccine (Nisbet et al., 2013). Although the efficacy of Tci-MIF-1 alone was not shown, this research presented optimism to continued investigation in vaccine-based control of nematode parasite infection in ruminants. Taken together, further research investigating the role of Oos-MIFs during development and infection, and their potential as vaccine candidates is warranted given that antibodies to Oos-MIF-1 do not cross-react with host MIF, but are capable of interfering with Oos-MIF function.

\section{Acknowledgements}

The authors wish to thank Mr. Eli Miramontes, Ms. Debora Hebert and Ms. Ruth Barfield for technical assistance. The authors wish to particularly thank Drs. Jitender Dubey and Oliver Kwok for assistance with immunohistochemistry and Dr. Benjamin Rosenthal for assistance with phylogenetic analysis. This research was supported by United States Department of Agriculture Agriculture, Research Service (USDA/ARS), USA in-house funding (WT) and National Institutes of Health (NIH, USA) R01AI042310 (RB).

\section{References}

Abe, R., Peng, T., Sailors, J., Bucala, R., Metz, C.N., 2001. Regulation of the CTL response by macrophage migration inhibitory factor. J. Immunol. 166, 747-753.

Abubucker, S., Zarlenga, D.S., Martin, J., Yin, Y., Wang, Z., McCarter, J.P., Gasbarree, L. Wilson, R.K., Mitreva, M., 2009. The transcriptomes of the cattle parasitic nematode Ostertagia ostartagi. Vet. Parasitol. 162, 89-99.

Aida, Y., Pabst, M.J., 1990. Removal of endotoxin from protein solutions by phase separation using Triton X-114. J. Immunol. Methods 132, 191-195.

Al-Abed, Y. Dabideen, D. Aljabari, B., Valster, A., Messmer, D., Ochani, M., Tanovic M., Ochani, K., Bacher, M., Nicoletti, F., Metz, C., Pavlov, V.A., Miller, E.J., Tracey, K.J., 2005. ISO- 1 binding to the tautomerase active site of MIF inhibits its proinflammatory activity and increases survival in severe sepsis. J. Biol. Chem. 280, $36541-36544$

Augustijn, K.D., Kleemann, R., Thompson, J., Kooistra, T., Crawford, C.E., Reece, S.E., Pain, A., Siebum, A.H., Janse, C.J., Waters, A.P., 2007. Functional characterization of the Plasmodium falciparum and $P$. berghei homologues of macrophage migration inhibitory factor. Infect. Immun. 75, 1116-1128.

Bacher, M., Metz, C.N., Calandra, T., Mayer, K., Chesney, J., Lohoff, M., Gemsa, D. Donnelly, T., Bucala, R., 1996. An essential regulatory role for macrophage migration inhibitory factor in T-cell activation. Proc. Natl. Acad. Sci. USA 93 7849-7854.

Bendrat, K., Al-Abed, Y., Callaway, D.J., Peng, T., Calandra, T., Metz, C.N., Bucala, R., 1997. Biochemical and mutational investigations of the enzymatic activity of macrophage migration inhibitory factor. Biochemistry 36, 15356-15362.

Bernacchi, S., Mercenne, G., Tournaire, C., Marquet, R., Paillart, J.C., 2011. Importance of the proline-rich multimerization domain on the oligomerization and nucleic acid binding properties of HIV-1 Vif. Nucleic Acids Res. 39, 2404-2415.

Bernhagen, J., Calandra, T., Mitchell, R.A., Martin, S.B., Tracey, K.J., Voelter, W., Manogue, K.R., Cerami, A., Bucala, R., 1993. MIF is a pituitary-derived cytokine that potentiates lethal endotoxaemia. Nature 365, 756-759.

Bernhagen, J., Krohn, R., Lue, H., Gregory, J.L., Zernecke, A., Koenen, R.R., Dewor, M., Georgiev, I., Schober, A., Leng, L., Kooistra, T., Fingerle-Rowson, G., Ghezzi, P., Kleemann, R., McColl, S.R., Bucala, R., Hickey, M.J., Weber, C., 2007. MIF is a noncognate ligand of CXC chemokine receptors in inflammatory and atherogenic cell recruitment. Nat. Med. 13, 587-596.

Bernhagen, J., Mitchell, R.A., Calandra, T., Voelter, W., Cerami, A., Bucala, R., 1994 Purification, bioactivity, and secondary structure analysis of mouse and human macrophage migration inhibitory factor (MIF). Biochemistry 33, 14144-14155.

Calandra, T., Bernhagen, J., Mitchell, R.A., Bucala, R., 1994. The macrophage is an important and previously unrecognized source of macrophage migration inhibitory factor. J. Exp. Med. 179, 1895-1902.

Calandra, T., Roger, T., 2003. Macrophage migration inhibitory factor: a regulator of innate immunity. Nat. Rev. Immunol. 3, 791-800.

Cho, Y., Jones, B.F., Vermeire, J.J., Leng, L., DiFedele, L., Harrison, L.M., Xiong, H. Kwong, Y.K., Chen, Y., Bucala, R., Lolis, E., Cappello, M., 2007. Structural and functional characterization of a secreted hookworm Macrophage Migration Inhibitory Factor (MIF) that interacts with the human MIF receptor CD74. J. Biol. Chem. 282, 23447-23456.

Cournia, Z., Leng, L., Gandavadi, S., Du, X., Bucala, R., Jorgensen, W.L., 2009. Discovery of human macrophage migration inhibitory factor (MIF)-CD74 antagonists via virtual screening. J. Med. Chem. 52, 416-424.

de Graaf, D.C., Peelman, L.J., Claerebout, E., Hilderson, H., Schallig, H.D., Vercruysse, J., 1995. Cloning and sequencing of an excretory/secretory antigen from Ostertagia ostertagi fourth-stage larvae containing multiple tandem repeats. Mol. Biochem. Parasitol. 72, 239-241.

Donnelly, S.C., Bucala, R., Metz, C.N., Grant, I.S., Robertson, C.R., Haslett, C., 1999 Macrophage migration inhibitory factor and acute lung injury. Chest 116, 111S

El-Turk, F. Cascella, M., Ouertatani-Sakouhi, H., Narayanan, R.L., Leng, L., Bucala, R. Zweckstetter, M., Rothlisberger, U., Lashuel, H.A., 2008. The conformational flexibility of the carboxy terminal residues $105-114$ is a key modulator of the catalytic activity and stability of macrophage migration inhibitory factor. Biochemistry 47, 10740-10756.

Falcone, F.H., Loke, P., Zang, X., MacDonald, A.S., Maizels, R.M., Allen, J.E., 2001. A Brugia malayi homolog of macrophage migration inhibitory factor reveals an 
important link between macrophages and eosinophil recruitment during nematode infection. J. Immunol. 167, 5348-5354.

Fingerle-Rowson, G.R., Bucala, R., 2001. Neuroendocrine properties of macrophage migration inhibitory factor (MIF). Immunol. Cell Biol. 79, 368-375.

Leng, L., Metz, C.N., Fang, Y., Xu, J., Donnelly, S., Baugh, J., Delohery, T., Chen, Y., Mitchell, R.A., Bucala, R., 2003. MIF signal transduction initiated by binding to CD74. J. Exp. Med. 197, 1467-1476.

Leutenegger, C.M., Alluwaimi, A.M., Smith, W.L., Perani, L., Cullor, J.S., 2000. Quantitation of bovine cytokine mRNA in milk cells of healthy cattle by realtime TaqMan polymerase chain reaction. Vet. Immunol. Immunopathol. 77, 275-287.

Livak, K.J., Schmittgen, T.D., 2001. Analysis of relative gene expression data using real-time quantitative PCR and the 2(-Delta Delta C(T)) Method. Methods 25, 402-408.

Lolis, E., Bucala, R., 2003. Macrophage migration inhibitory factor. Expert. Opin. Ther. Targets. 7, 153-164.

Lubetsky, J.B., Dios, A., Han, J., Aljabari, B., Ruzsicska, B., Mitchell, R., Lolis, E., AlAbed, Y., 2002. The tautomerase active site of macrophage migration inhibitory factor is a potential target for discovery of novel anti-inflammatory agents. J. Biol. Chem. 277, 24976-24982.

Lubetsky, J.B., Swope, M., Dealwis, C., Blake, P., Lolis, E., 1999. Pro-1 of macrophage migration inhibitory factor functions as a catalytic base in the phenylpyruvate tautomerase activity. Biochemistry 38, 7346-7354.

Marson, A.L., Tarr, D.E., Scott, A.L., 2001. Macrophage migration inhibitory factor (mif) transcription is significantly elevated in Caenorhabditis elegans daue larvae. Gene 278, 53-62.

Mischke, R., Kleemann, R., Brunner, H., Bernhagen, J., 1998. Cross-linking and mutational analysis of the oligomerization state of the cytokine macrophage migration inhibitory factor (MIF). FEBS Lett. 427, 85-90.

Nisbet, A.J., Bell, N.E., McNeilly, T.N., Knox, D.P., Maizels, R.M., Meikle, L.I. Wildblood, L.A., Matthews, J.B., 2010. A macrophage migration inhibitory factor-like tautomerase from Teladorsagia circumcincta (Nematoda: Strongylida). Parasite Immunol. 32, 503-511.

Nisbet, A.J., McNeilly, T.N., Wildblood, L.A., Morrison, A.A., Bartley, D.J., Bartley, Y., Longhi, C., McKendrick, I.J., Palarea-Albaladejo, J., Matthews, J.B., 2013. Successful immunization against a parasitic nematode by vaccination with recombinant proteins. Vaccine 31, 4017-4023.

Onodera, S., Suzuki, K., Matsuno, T., Kaneda, K., Takagi, M., Nishihira, J., 1997 Macrophage migration inhibitory factor induces phagocytosis of foreign particles by macrophages in autocrine and paracrine fashion. Immunology 92 , $131-137$.

Pastrana, D.V., Raghavan, N., FitzGerald, P., Eisinger, S.W., Metz, C., Bucala, R., Schleimer, R.P., Bickel, C., Scott, A.L., 1998. Filarial nematode parasites secrete a homologue of the human cytokine macrophage migration inhibitory factor. Infect. Immun. 66, 5955-5963.

Pennock, J.L., Behnke, J.M., Bickle, Q.D., Devaney, E., Grencis, R.K., Isaac, R.E., Joshua, G.W., Selkirk, M.E., Zhang, Y., Meyer, D.J., 1998. Rapid purification and characterization of L-dopachrome-methyl ester tautomerase (macrophagemigration-inhibitory factor) from Trichinella spiralis, Trichuris muris and Brugia pahangi. Biochem. J. 335 (Pt 3), 495-498.

Philo, J.S., Yang, T.H., LaBarre, M., 2004. Re-examining the oligomerization state of macrophage migration inhibitory factor (MIF) in solution. Biophys. Chem. 108, 77-87.

Qu, G., Fetterer, R., Jenkins, M., Leng, L., Shen, Z., Murphy, C., Han, W., Bucala, R., Tuo, W., 2013. Characterization of Neospora caninum macrophage migration inhibitory factor. Exp. Parasitol. 135, 246-256.

Richardson, J.M., Morrison, L.S., Bland, N.D., Bruce, S., Coombs, G.H., Mottram, J.C. Walkinshaw, M.D. 2009. Structures of Leishmania major orthologues of macrophage migration inhibitory factor. Biochem. Biophys. Res. Commun. $380,442-448$.

Roger, T., Chanson, A.L., Knaup-Reymond, M., Calandra, T., 2005. Macrophage migration inhibitory factor promotes innate immune responses by suppressing glucocorticoid-induced expression of mitogen-activated protein kinase phosphatase-1. Eur. J. Immunol. 35, 3405-3413.

Roger, T., Froidevaux, C., Martin, C., Calandra, T., 2003. Macrophage migration inhibitory factor (MIF) regulates host responses to endotoxin through modulation of Toll-like receptor 4 (TLR4). J. Endotoxin. Res. 9, 119-123.

Schnable, P.S., Ware, D., Fulton, R.S., Stein, J.C., Wei, F., Pasternak, S., Liang, C., Zhang, J., Fulton, L., Graves, T.A., Minx, P., Reily, A.D., Courtney, L., Kruchowski, S.S. Tomlinson, C., Strong, C., Delehaunty, K., Fronick, C., Courtney, B., Rock, S.M., Belter, E., Du, F., Kim, K., Abbott, R.M., Cotton, M., Levy, A., Marchetto, P., Ochoa, K., Jackson, S.M., Gillam, B., Chen, W., Yan, L., Higginbotham, J., Cardenas, M. Waligorski, J., Applebaum, E., Phelps, L., Falcone, J., Kanchi, K., Thane, T., Scimone, A., Thane, N., Henke, J., Wang, T., Ruppert, J., Shah, N., Rotter, K., Hodges, J., Ingenthron, E., Cordes, M., Kohlberg, S., Sgro, J., Delgado, B., Mead, K., Chinwalla, A., Leonard, S., Crouse, K., Collura, K., Kudrna, D., Currie, J., He, R. Angelova, A., Rajasekar, S., Mueller, T., Lomeli, R., Scara, G., Ko, A., Delaney, K., Wissotski, M., Lopez, G., Campos, D., Braidotti, M., Ashley, E., Golser, W., Kim, H. Lee, S., Lin, J. Dujmic, Z, Kim, W. Talag, J., Zuccolo, A, Fan, C., Sebastian, A Kramer, M., Spiegel, L., Nascimento, L., Zutavern, T., Miller, B., Ambroise, C., Muller, S., Spooner, W., Narechania, A., Ren, L., Wei, S., Kumari, S., Faga, B., Levy, M.J., McMahan, L., Van, B.P., Vaughn, M.W., Ying, K., Yeh, C.T., Emrich, S.J., Jia, Y., Kalyanaraman, A., Hsia, A.P., Barbazuk, W.B., Baucom, R.S., Brutnell, T.P., Carpita, N.C., Chaparro, C., Chia, J.M., Deragon, J.M., Estill, J.C., Fu, Y., Jeddeloh, J.A., Han,
Y., Lee, H., Li, P., Lisch, D.R., Liu, S., Liu, Z., Nagel, D.H., McCann, M.C., SanMiguel, P., Myers, A.M., Nettleton, D., Nguyen, J., Penning, B.W., Ponnala, L., Schneider, K.L., Schwartz, D.C., Sharma, A., Soderlund, C., Springer, N.M., Sun, Q., Wang, H., Waterman, M., Westerman, R., Wolfgruber, T.K., Yang, L., Yu, Y., Zhang, L., Zhou, S., Zhu, Q. Bennetzen, J.L., Dawe, R.K. Jiang, J., Jiang, N., Presting, G.G., Wessler, S.R., Aluru, S., Martienssen, R.A., Clifton, S.W., McCombie, W.R., Wing, R.A., Wilson, R.K., 2009. The B73 maize genome: complexity, diversity, and dynamics. Science 326, 1112-1115.

Sharma, R., Hoti, S.L., Meena, R.L., Vasuki, V., Sankari, T., Kaliraj, P., 2012. Molecular and functional characterization of macrophage migration inhibitory factor (MIF) homolog of human from lymphatic filarial parasite Wuchereria bancrofti. Parasitol. Res. 111, 2035-2047.

Shi, X., Leng, L., Wang, T., Wang, W., Du, X., Li, J., McDonald, C., Chen, Z., Murphy, J.W., Lolis, E., Noble, P., Knudson, W., Bucala, R., 2006. CD44 is the signaling component of the macrophage migration inhibitory factor-CD74 receptor complex. Immunity 25, 595-606.

Shukla, A., Burton, N.M., Jayaraman, P.S., Gaston, K., 2012. The proline rich homeodomain protein PRH/Hhex forms stable oligomers that are highly resistant to denaturation. PLoS. One. 7, e35984.

Smith, S.K., Nisbet, A.J., Meikle, L.I., Inglis, N.F., Sales, J., Beynon, R.J., Matthews, J.B., 2009. Proteomic analysis of excretory/secretory products released by Teladorsagia circumcincta larvae early post-infection. Parasite Immunol. 31, 10-19.

Sommerville, C., Richardson, J.M., Williams, R.A., Mottram, J.C., Roberts, C.W., Alexander, J., Henriquez, F.L., 2013. Biochemical and immunological characterization of Toxoplasma gondii macrophage migration inhibitory factor. J. Biol. Chem. 288, 12733-12741.

Stamps, S.L., Fitzgerald, M.C., Whitman, C.P., 1998. Characterization of the role of the amino-terminal proline in the enzymatic activity catalyzed by macrophage migration inhibitory factor. Biochemistry 37, 10195-10202.

Sun, H.W., Bernhagen, J., Bucala, R., Lolis, E., 1996a. Crystal structure at 2.6-A resolution of human macrophage migration inhibitory factor. Proc. Natl. Acad. Sci. USA 93, 5191-5196.

Sun, H.W., Swope, M., Cinquina, C., Bedarkar, S., Bernhagen, J., Bucala, R., Lolis, E., 1996b. The subunit structure of human macrophage migration inhibitory factor: evidence for a trimer. Protein Eng. 9, 631-635.

Suzuki, M., Sugimoto, H., Nakagawa, A., Tanaka, I., Nishihira, J., Sakai, M., 1996. Crystal structure of the macrophage migration inhibitory factor from rat liver. Nat. Struct. Biol. 3, 259-266.

Tabata, S., Kaneko, T. Nakamura, Y., Kotani, H., Kato, T. Asamizu, E., Miyajima, N., Sasamoto, S., Kimura, T., Hosouchi, T., Kawashima, K., Kohara, M., Matsumoto, M., Matsuno, A., Muraki, A., Nakayama, S., Nakazaki, N., Naruo, K., Okumura, S., Shinpo, S., Takeuchi, C., Wada, T., Watanabe, A., Yamada, M., Yasuda, M., Sato, S., de la Bastide, M., Huang, E., Spiegel, L., Gnoj, L., O’Shaughnessy, A., Preston, R., Habermann, K., Murray, J., Johnson, D., Rohlfing, T., Nelson, J., Stoneking, T., Pepin, K., Spieth, J., Sekhon, M., Armstrong, J., Becker, M., Belter, E., Cordum, H., Cordes, M., Courtney, L., Courtney, W., Dante, M., Du, H., Edwards, J., Fryman, J., Haakensen, B., Lamar, E., Latreille, P., Leonard, S., Meyer, R., Mulvaney, E. Ozersky, P., Riley, A., Strowmatt, C., Wagner-McPherson, C., Wollam, A., Yoakum, M., Bell, M., Dedhia, N., Parnell, L., Shah, R., Rodriguez, M., See, L.H., Vil, D., Baker, J., Kirchoff, K., Toth, K., King, L., Bahret, A., Miller, B., Marra, M., Martienssen, R., McCombie, W.R., Wilson, R.K., Murphy, G., Bancroft, I., Volckaert, G., Wambutt, R., Dusterhoft, A., Stiekema, W., Pohl, T., Entian, K.D. Terryn, N., Hartley, N., Bent, E., Johnson, S., Langham, S.A., McCullagh, B., Robben, J., Grymonprez, B., Zimmermann, W., Ramsperger, U., Wedler, H., Balke, K., Wedler, E., Peters, S., van, S.M., Dirkse, W., Mooijman, P., Lankhorst, R.K., Weitzenegger, T., Bothe, G., Rose, M., Hauf, J., Berneiser, S., Hempel, S., Feldpausch, M., Lamberth, S., Villarroel, R., Gielen, J., Ardiles, W., Bents, O., Lemcke, K., Kolesov, G., Mayer, K., Rudd, S., Schoof, H., Schueller, C., Zaccaria, P., Mewes, H.W., Bevan, M., Fransz, P., 2000. Sequence and analysis of chromosome 5 of the plant Arabidopsis thaliana. Nature 408, 823-826.

Tan, T.H., Edgerton, S.A., Kumari, R., McAlister, M.S., Roe, S.M., Nagl, S., Pearl, L.H., Selkirk, M.E., Bianco, A.E., Totty, N.F., Engwerda, C., Gray, C.A., Meyer, D.J., 2001. Macrophage migration inhibitory factor of the parasitic nematode Trichinella spiralis. Biochem. J. 357, 373-383.

Thacker, T.C., Palmer, M.V., Waters, W.R., 2007. Associations between cytokine gene expression and pathology in Mycobacterium bovis infected cattle. Vet. Immunol. Immunopathol. 119, 204-213.

Vermeire, J.J., Cho, Y., Lolis, E., Bucala, R., Cappello, M., 2008. Orthologs of macrophage migration inhibitory factor from parasitic nematodes. Trends Parasitol. 24, 355-363.

Williams, J.C., Knox, J.W., Loyacano, A.F., 1993. Epidemiology of Ostertagia ostertagi in weaner-yearling cattle. Vet. Parasitol. 46, 313-324.

Williams, J.C., Knox, J.W., Marbury, K.S., Kimball, M.D., Baumann, B.A., Snider, T.G., 1987. The epidemiology of Ostertagia ostertagi and other gastrointestinal nematodes of cattle in Louisiana. Parasitology 95 (Pt 1), 135-153.

Younis, A.E., Soblik, H., Ajonina-Ekoti, I., Erttmann, K.D., Luersen, K., Liebau, E., Brattig, N.W., 2012. Characterization of a secreted macrophage migration inhibitory factor homologue of the parasitic nematode Strongyloides acting at the parasite-host cell interface. Microbes. Infect. 14, 279-289.

Zang, X., Taylor, P., Wang, J.M., Meyer, D.J., Scott, A.L., Walkinshaw, M.D., Maizels, R.M., 2002. Homologues of human macrophage migration inhibitory factor from a parasitic nematode. Gene cloning, protein activity, and crystal structure. J. Biol. Chem. 277, 44261-44267. 